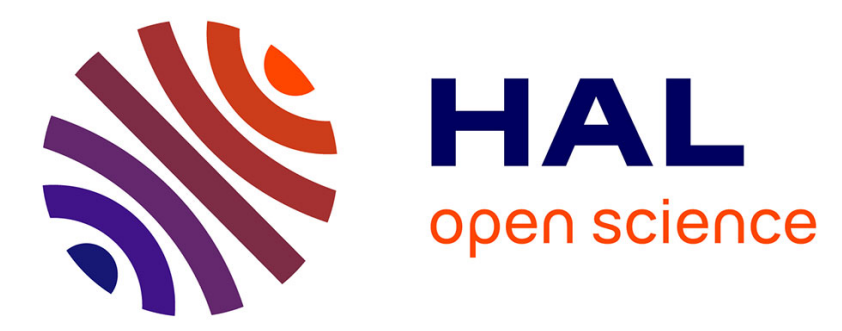

\title{
Melilite-bearing lavas in Mayotte (France): An insight into the mantle source below the Comores
}

Anne-Aziliz Pelleter, Martial Caroff, Carole Cordier, Patrick Bachèlery, Pierre Nehlig, Delphine Debeuf, Nicolas Arnaud

\section{- To cite this version:}

Anne-Aziliz Pelleter, Martial Caroff, Carole Cordier, Patrick Bachèlery, Pierre Nehlig, et al.. Melilitebearing lavas in Mayotte (France): An insight into the mantle source below the Comores. Lithos, 2014, 208-209, pp.281-297. 10.1016/j.lithos.2014.09.012 . insu-01089376

\section{HAL Id: insu-01089376 https://hal-insu.archives-ouvertes.fr/insu-01089376}

Submitted on 5 Dec 2014

HAL is a multi-disciplinary open access archive for the deposit and dissemination of scientific research documents, whether they are published or not. The documents may come from teaching and research institutions in France or abroad, or from public or private research centers.
L'archive ouverte pluridisciplinaire HAL, est destinée au dépôt et à la diffusion de documents scientifiques de niveau recherche, publiés ou non, émanant des établissements d'enseignement et de recherche français ou étrangers, des laboratoires publics ou privés. 
1 Melilite-bearing lavas in Mayotte (France): an insight into the mantle

4 Anne-Aziliz Pelleter ${ }^{\mathrm{a}, 1}$, Martial Caroff ${ }^{\mathrm{a}, *}$, Carole Cordier $^{\mathrm{b}, \mathrm{c}}$, Patrick Bachelery ${ }^{\mathrm{d}}$, Pierre Nehlig $^{\mathrm{e}}$, Delphine Debeuf ${ }^{\mathrm{f}}$, Nicolas Arnaud ${ }^{\mathrm{g}}$ Ferrand Cédex, France

${ }^{\text {e }}$ Bureau de Recherches Géologiques et Minières, 3, avenue Claude-Guillemin, BP 36009, F-

${ }^{\mathrm{f}}$ Laboratoire GéoSciences Réunion, Faculté des Sciences et Technologies, 15, avenue René Cassin, CS 92003, F-97744 Saint-Denis Cédex 9, La Réunion, France

${ }^{\mathrm{g}}$ Géosciences Montpellier, UMR 5243, CC 60, Université Montpellier 2, Place E. Bataillon, F-34095 Montpellier Cédex 5, France

* Corresponding author: caroff@ univ-brest.fr

${ }^{1}$ Present address : UMR CNRS n ${ }^{\circ} 7327$, Institut des Sciences de la Terre d'Orléans, 
Keywords: Comores; ocean island basalts; olivine melilitite; HIMU; mantle heterogeneity; metasomatism

\section{Introduction}

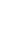

Olivine melilitites are alkaline and ultracalcic basic igneous rocks rich in melilite, a calcic sorosilicate, and devoid of feldspar. They are thought to be produced by low degree of partial melting of a $\mathrm{CO}_{2}$-rich mantle source in both continental and oceanic contexts

(Gudfinnsson and Presnall, 2005; Dasgupta et al., 2007). In continental zones, they are found at or near rifting zones, often in association with carbonatites. In the African continent, (olivine) melilitites have been observed in Sahara (Dautria et al., 1992), East African Rift (Bailey et al., 2005; Dawson, 2012; Mattsson et al., 2013), South Africa (Rogers et al., 1992; Janney et al., 2002), and Madagascar (Melluso et al., 2011). In oceanic setting, the olivine melilitites are produced in intraplate volcanoes (Maaløe et al., 1992; Hoernle and Schmincke, 1993). They correspond generally to post-erosional, late units (Brey, 1978). In the vicinity of the Africa continent, olivine melilitites have been collected in Gran Canaria (Brey, 1978; Hoernle and Schmincke, 1993) and Cape Verde Islands (Brey, 1978). Several authors have highlighted the chemical resemblance, for incompatible trace element and isotopic ratios, between (olivine) melilitites and ocean island basalts (OIB), sometimes with a HIMU (or high $\mu$, where $\mu={ }^{238} \mathrm{U} /{ }^{204} \mathrm{~Pb}$ ) affinity (Rogers et al., 1992; Wilson et al., 1995; Janney et al., 2002). The Comores Archipelago, composed of four volcanic islands (Mayotte, Anjouan, Moheli, and Grande Comore) is located in the Mozambique Channel between the continental blocks of Africa and Madagascar (Fig. 1). The initial volcanism period of the oldest island Mayotte - onto the ocean floor is estimated to be ca. 15-10 Ma (Nougier et al., 1986), whereas the Karthala volcano of Grande Comore (the youngest island) is still active. 
The mantle beneath the Comores is probably metasomatized, with modal amphibole and/or phlogopite (Späth et al., 1996; Class and Goldstein, 1997). In fact, Coltorti et al. (1999) evidenced a $\mathrm{CO}_{2}$-related cryptic metasomatism episode beneath Grande Comore. The origin of the Comores volcanism is attributed by Hajash and Armstrong (1972) and Emerick and Duncan (1982) to the upwelling of a mantle plume. Nougier et al. (1986) proposed that the Comorian magmas derive from the upper mantle, beneath an ocean-continent transitional crust structured by old and deep lithospheric fractures, which were reactivated during late Tertiary. Four Comores lavas - one sample from Moheli and the three analyzed samples from Anjouan (Reisberg et al., 1993; Späth et al., 1996; Salters and White, 1998) - have a more radiogenic $\mathrm{Pb}$ composition than the other Indian OIB. They display an isotopic signature close to that of the Atlantic islands near the western African coast, as Cape Verde and Canary Islands (Sushchevskaya et al., 2013).

The present study of Mayotte Island (Comores Archipelago), based on new petrological and geochemical data, reveals the coexistence of a large number of melilitebearing (including olivine melilitites) and HIMU-like lavas (with ${ }^{206} \mathrm{~Pb} /{ }^{204} \mathrm{~Pb}>20$ ). Mayotte Island is thus a good example for studying the genesis of melilite-bearing lavas and their relation with a specific mantle composition.

\section{Geological setting}

Mayotte is the oldest island of the Comores archipelago (Fig. 1), emplaced, while intraplate, in an active tectonic area. The present-day geography of the area is the consequence of the Permian-Trias Karoo NW-SE rifting, which resulted in the separation between Gondwana and Indian-Madagascan continental blocks (Malod et al., 1991; Piqué, 1999). The oceanic basins of Somalia and Mozambique opened during the Jurassic, while the 
Madagascar Island drifted southwards along the Davie Ridge. The main part of the sedimentary products in the Mozambique Channel results from the erosion of the Davie Ridge surrected during an Eocene compression phase (Leclaire et al., 1989). Since the middle Miocene, the tectonic regime in the Mozambique Channel is dominated by E-NE-W-SW extension, also identified in the East African Rift and in Madagascar (Bertil and Regnoult, 1998; Piqué, 1999).

Although the volcano morphology in the Comores archipelago is rather consistent with a chronological progression of the volcanism northwestwards (freshest reliefs in Grande Comore; presence of a coral reef only in Mayotte and, to a less extend, in Moheli: Fig. 1), the K-Ar geochronological data of the archipelago suggest a more complex history (Fig. 1). With exception of Grande Comore, in which old lavas do not crop out, each island displays a Neogene volcanic activity (shield stage?) together with a more recent one. The oldest subaerial lavas of the archipelago are found in Mayotte, consistently with its eroded morphology and the presence of a large coral reef. Only one coarse-grained rock of Anjouan is older (11.1 $\pm 0.5 \mathrm{Ma}$, Nougier et al., 1986), very different from the shield lavas (from 3.9 $\pm 0.3 \mathrm{Ma}$ to $1.5 \pm 0.2 \mathrm{Ma}$, Nougier et al., 1986). However, no dating is available for the rocks constituting the submarine flanks of the islands. It is therefore very difficult to reasonably establish, or not, a chronological progression of volcanism throughout the archipelago.

Mayotte is located $300 \mathrm{~km}$ westward of Madagascar and $70 \mathrm{~km}$ southwestward of Anjouan (Fig. 1). It is constituted of two main volcanic islands (Grande Terre and Petite Terre: $348 \mathrm{~km}^{2}$ and $16 \mathrm{~km}^{2}$ in surface, respectively) and around twenty islets, within a lagoon of $1100 \mathrm{~km}^{2}$ bordered by a $160 \mathrm{~km}$-long coral reef (Fig. 2a). Grande Terre is a north-south lengthened island, culminating at $660 \mathrm{~m}$ (Bénara Mount). The emerged reliefs correspond to the superstructure of two coalescent eroded shield volcanoes, subsiding for 1.5 Ma (Debeuf, 
101 2004; Nehlig et al., 2013). Petite Terre is a $5 \mathrm{~km}$-long island located $4 \mathrm{~km}$ eastward of Grande

102 Terre (Fig. 2d).

103

104

\section{Sampling and analytical techniques}

105

106

\subsection{Sampling}

107

108

The rocks presented here were collected during three field trips, in 2001 (sampling: D.

109

Debeuf and P. Bachelery), 2010 and 2011 (sampling: P. Nehlig, F. Lacquement, and J.

110

Bernard, with the financial and logistic support of the French BRGM).

Mayotte Island is characterized by an intense lateritic weathering and an important

112 plant cover. Consequently, the main part of the volcanic substratum cannot be sampled.

113 Although only the freshest rocks have been collected, a residual meteoric alteration induces

114 relatively high loss on ignition (LOI) values in several samples. As all the samples having a

115 LOI > $4.6 \mathrm{wt} . \%$ are affected by significant argillaceous / hydroxidic alteration, we have

116 rejected them for the geochemical study.

117 Among about a hundred of samples collected in 2001, 24 lavas have been dated; 51

118 samples have been analyzed for major and trace elements, 17 for ${ }^{87} \mathrm{Sr} /{ }^{86} \mathrm{Sr}, 23$ for ${ }^{143} \mathrm{Nd} /{ }^{144} \mathrm{Nd}$

119 isotopes, and 8 for $\mathrm{Pb}$ isotopes. Among the 35 samples collected in 2010 and 2011: 19

120 samples have been analyzed for major and trace elements, 10 for ${ }^{87} \mathrm{Sr} /{ }^{86} \mathrm{Sr}$ isotopes, and 14 for

$121 \mathrm{Nd}$ and $\mathrm{Pb}$ isotopes. A selection of geochronological and chemical data is shown in Tables 1,

122 2, and 3. The complete dataset is given in the supplementary Table S1. 
Bulk rock samples (flows, dykes and domes) were dated by the ${ }^{40} \mathrm{Ar} /{ }^{39} \mathrm{Ar}$ method.

127 Analyses were performed on the 150- $250 \mu \mathrm{m}$-size groundmass fraction. For each sample, one or more aliquots on different separates (typically feldspar and volcanic glass) were irradiated on January 2002 at the McMaster reactor, Ontario, in the $5 \mathrm{C}$ position for $26 \mathrm{~h}$ under a $10^{18}$ neutrons $\mathrm{cm}^{-2} \mathrm{~s}^{-1}$ flux. The irradiation standard is a Fish Canyon sanidine standard with an age of $28.02 \pm 0.16 \mathrm{Ma}$ (Renne et al., 1998), with reproductive values within $0.6 \%$.

Ages were obtained at the University of Montpellier 2, following a protocol similar to that described in Arnaud et al. (2003) and Garcia et al. (2003). Details on the analytical conditions are available from the authors upon request. Age given from age spectra are weighted mean plateaus (Fleck et al., 1977) or simple mean ages. The latter case corresponds to the situation where either subsequent steps overlap only at the $1 \sigma$ level or total ${ }^{39} \mathrm{Ar}$ cumulated from these steps is insufficient to define a classical plateau. All errors from age spectra take the error on the $\mathrm{J}$ factor into account. Plateau criterions being rarely achieved, sometimes simple mean age is given. The isochron ages are obtained in an inverse isochron diagram of ${ }^{36} \mathrm{Ar} /{ }^{40} \mathrm{Ar}$ versus ${ }^{39} \mathrm{Ar} /{ }^{40} \mathrm{Ar}$ (Roddick et al., 1980), which allows homogeneous excess components to be individualized in many occasions. Errors on age and intercept age include individual errors on each point and linear regression by York's method (York, 1969). The goodness of it relative to individual errors is measured by Mean Square Weighted Deviation (MSWD).

\subsection{Mineral and whole rock analyses}

Mineral compositions have been determined using a Cameca SX-100 electron microprobe (Microsonde Ouest, Brest, France) with an acceleration voltage of $15 \mathrm{kV}$ and a beam current of $20 \mathrm{nA}$. Some high precision analyses of olivine were acquired using a JEOL 
151 JXA-8230 electron microprobe (ISTerre, Grenoble, France) with an acceleration voltage of 25

$152 \mathrm{kV}$ and a beam current of $900 \mathrm{nA}$.

153 Major and trace element analyses for the rocks sampled in 2001 were determined at

154 the CRPG (Centre de Recherches Pétrographiques et Géochimiques, Nancy, France), whereas

155 samples collected in 2010-2011 were analyzed at the PSO/IUEM (Pôle Spectrométrie Océan,

156 Institut Universitaire Européen de la Mer, Brest, France). Whole-rock major elements were

157 analyzed by inductively coupled plasma atomic emission spectrometry (ICP-AES) following

158 the analytical method described by Cotten et al. (1995). Relative standard deviations are < $2 \%$

$159\left(<1 \%\right.$ for $\left.\mathrm{SiO}_{2}\right)$. Whole-rock trace elements were analyzed by inductively coupled plasma

160 mass spectrometry (ICP-MS) following the sample preparation and analysis method of Barrat

161 et al. (1996). Relative standard deviations are $<5 \%$ for most of the trace elements and $<10 \%$

162 for $\mathrm{Nb}, \mathrm{Gd}, \mathrm{Tb}, \mathrm{Ta}, \mathrm{Ni}, \mathrm{Zn}$ and $\mathrm{Rb}$. The concentrations found in the Mayotte OIB are well

163 above the detection limits for all the trace elements analyzed.

$164 \quad$ Sr and some Nd isotopic ratios were measured by thermal ionization mass

165 spectrometry (TIMS, Laboratoire Magmas et Volcans, Clermont-Ferrand, France and

$166 \mathrm{PSO} / \mathrm{IUEM} / \mathrm{IFREMER}$, Brest, France), while $\mathrm{Pb}$ and some Nd isotopic ratios were measured

167 on a multicollector ICP-MS (PSO/IFREMER, Brest, France). Samples were leached in 2N

$168 \mathrm{HCl}$ for about one hour and rinsed three times in ultrapure water to remove weathering effect.

169 The protocol for element separation is described in Chauvel et al. (2011). Measured blanks

170 are lower than 20 picograms (pg) for $\mathrm{Nd}, 60 \mathrm{pg}$ for $\mathrm{Sr}$ and $100 \mathrm{pg}$ for $\mathrm{Pb}$ (except one analysis

171 session with $300 \mathrm{pg}$ blank). Values used for mass fractionation corrections and relative

172 standard deviations are given in Table 3.

173

174 4. Geochronology of Mayotte

175 
Four volcanic domains have been recognized on Mayotte Island from geological and geomorphological observations, ages available in the literature (Hajash and Armstrong, 1972; Emerick and Duncan, 1982; Nougier et al, 1986; McDougall unpublished in Debeuf, 2004), and new ${ }^{40} \mathrm{Ar} /{ }^{39} \mathrm{Ar}$ ages obtained on 24 samples (Table 1).

The most eroded - and thus oldest - area is the southern part of the main island (Fig. $2 b$ ), where the hydrographic network is intensely erosive and most headlands correspond to inverted reliefs. The main building volcanic phase (> 10.6- 3.0 Ma) is mainly formed by alkali basalt, basanite and olivine nephelinite lava flows (Fig. 2c), strongly weathered to lateritic products. This phase ended with the intrusion of around fifteen phonolitic protrusions, associated with nephelinitic/phonolitic lava flows and pyroclastic density currents (3.9-3.1 Ma). The post-shield phase began with the emplacement of the tephriphonolitic/phonolitic Combani massif circa 2.4 Ma ago. The last events in the south domain are emission of pyroxene-bearing basanitic and nephelinitic lava flows (ca. 2.0- 1.5 Ma).

The northwest domain is characterized by sharp reliefs of moderately weathered basaltic-basanitic lava flow piles, contemporaneous to the southern main building phase (> 7.1- 4.0 Ma). These lavas constitute a second shield volcano, which would have emerged after the southern one (Stieljes, 1988). Lavas are cut by a basaltic intrusive network (sills and $\mathrm{N}-\mathrm{S}$-trending dykes). This volcanism was followed by an extension-related mafic magmatism, at about $\sim 4.0-<1.0 \mathrm{Ma}$, which renewed the reliefs. The two melilititic lava flows were probably emplaced during this event. Phonolitic domes (3.3 and $2.5 \mathrm{Ma}$ ) are especially rare (Fig. 2c).

The north central sector of Grande Terre is characterized by the least eroded, youngest reliefs (Fig. 2b). This is consistent with lava ages mainly comprised between 2.4 and $0.8 \mathrm{Ma}$, i.e. more recent than in both south and northwest domains. Two older samples have been dated at 3.4 Ma (Hajash and Armstrong, 1972) and 3.35 Ma (Emerick and Duncan, 1982), but 
they have not been analyzed for major and trace elements. From west to east, the north central sector is composed of: (1) the Digo massif, made of basaltic-tephritic lava flows; and (2) the Mtsapéré stratovolcano (basaltic-tephritic lava flows intruded by phonolitic protrusions, Fig. 2c), lying on the northwest shield formations.

The fourth volcanic zone is a recent explosive complex comprising small pyroclastic edifices (tuff rings and cones) built by phreatomagmatism and strombolian eruptions along the east coast of Grande Terre and in Petite Terre (Fig. 2c). The activity is estimated from 500000 to 150000 years in Grande Terre and up to 4000 years in Petite Terre, where the volcanic edifices lay on a Holocene barrier reef younger than 9000 years (Camoin et al., 2004). The subaerial explosive volcanoes lay on lateritized lava flows in Grande Terre. The first strombolian phase built edifices with interbedded lava flows and pyroclastic levels (scoriaceous blocks and lapilli, and ash). Then, the volcanism became phreatoplinian, with pumice-bearing tuff ring structures. Two of them crop out in Grande Terre and four in Petite Terre (three in the eastern part and a fourth in the southernmost area, Fig. 2c).

\section{Petrology}

\subsection{Lavas and hypabyssal rocks}

The mineral assemblage of the studied lavas is presented in Fig. 3. The petrographic nomenclature is based on mineralogy, total alkali-silica (TAS) and basanite-nephelinitemelilitite classification schemes of Le Bas et al. (1986) and Le Bas (1989), respectively (Figs. 4 and 5).

Most of the lava flows of south and northwest domains are alkali basalts and basanites. Lavas are usually porphyritic, sometimes cumulative (> 35 vol.\% phenocrysts), with 
clinopyroxene and/or olivine (Fo F9-85 $)$ phenocrysts. Groundmass generally has a microlitic texture. It is constituted of clinopyroxene (fassaite-diopside), olivine $\left(\mathrm{Fo}_{62-81}\right)$, plagioclase $\left(\mathrm{An}_{47-64}\right)$, nepheline, Fe-Ti oxides and apatite. Perovskite crystals have been identified as inclusions in clinopyroxene phenocrysts of one basanite from the south domain.

Two olivine melilitite lavas were collected near Mtsangamouji in the northwest domain. They are porphyritic with zoned olivine phenocrysts (Fo84-88) immersed in a microlitic groundmass constituted of melilite, olivine ( $\left.\mathrm{Fo}_{79-84}\right)$, titanomagnetite, apatite, clinopyroxene, and tiny nepheline. One sample displays mingling features.

Olivine-free and olivine-bearing nephelinites occur as lava flows or dykes in the south domain and in a few areas of the northwest domain. They have a porphyritic texture with phenocrysts of clinopyroxene (fassaite-diopside) and nepheline. Groundmass crystals include nepheline, clinopyroxene, Fe-Ti oxides, and apatite. Olivine phenocrysts $\left(\mathrm{Fo}_{74-87}\right)$ and microcrysts $\left(\mathrm{Fo}_{69-78}\right)$ are only present in the olivine nephelinites, whereas hornblende, aegirine-augite, perovskite and titanite are detected only in olivine-free nephelinites. Microcrystals of melilite ( $<10$ vol.\%) have been identified in two olivine nephelinites (PN2 and PN12f).

Tephritic and tephriphonolitic lavas occur in the south and north central domains. They have a porphyric fluidal microlitic texture. Phenocrysts are zoned augite and kaersutite, whereas groundmass includes plagioclase, clinopyroxene, Fe-Ti oxides, hastingsite and apatite. Tephriphonolites can be distinguished from tephrites by the presence of both Kfeldspar as phenocrysts and arfvedsonite and aegirine-augite as microcrysts.

Phonolites occur as protusions or as derived lava flows, mainly in the south and north central domains and, sparsely, in the northwest one. They have a porphyritic microlitic texture, sometimes fluidal. Diopside, hornblende, K-feldspar, nepheline, and apatite occur as 
250 phenocrysts and microcrysts. Moreover, the groundmass contains titanite, aegirine-augite,

251 ferro-arfvedsonite, ferro-eckermannite and Fe-Ti oxides.

\subsection{Pyroclastites and cumulates}

Two types of pyroclastic formations have been identified: stombolian and phreatoplinian deposits, mainly located in the most recent domains of Mayotte (NE coast of Grande Terre and Petite Terre), and only sparsely represented in the older north central and south domains (Fig. 2c). Elements of the primary pyroclastic breccias are locally reworked as volcanogenic sedimentary deposits.

The strombolian edifices are small reddened scoria cones, composed of basaltic

261 indurated lapilli- and bomb-sized fragments alternating with lava flows and ash levels.

262 Locally, blocks of sedimentary rock (sandstone, arkose) are embedded in the breccias. The 263 fragments bear iddingsitized olivine, pyroxene, nepheline and Fe-Ti oxides.

The phreatoplinian deposits are constituted of meter-sized interbedded sequences of pumice levels and hyaloclastite layers. Pumices range in size from 5 to $50 \mathrm{~cm}$. They have a vesicular hyaloporphyric texture, with euhedral phenocrysts of K-feldspar, hornblende, and Fe-Ti oxides. Among the xenoliths, fragments of coral, lavas and scoria, dunitic and pyroxenitic cumulates are present. The basanitic xenolith PN5b, cumulative in olivine and clinopyroxene, has been found in the pumice sample PN5a.

271 essexites and ijolites.

\section{Geochemistry}




\subsection{Major elements}

The subsequent geochemical study focuses on lavas and hypabyssal rocks (dykes and protrusions) of Grande Terre, together with pumices of Petite Terre. Major and trace element compositions of representative samples from Mayotte are listed in Table 2. The TAS diagram of Le Bas et al. (1986) (Fig. 4) can be used to evidence a large alkaline association in Mayotte from alkali basalts (only four analyzed samples), basanites and foidites to phonolites through intermediate lavas. Two trends are observed (Fig. 4): the first one, including mainly the south lavas, one basalt apart (M41), is highly silica-undersaturated; the second one, including the rocks from the three other domains, is moderately silica-undersaturated. Mafic rocks $(\mathrm{MgO}>$ $5 \mathrm{wt} . \%)$ are divided into three groups on the basis of silica-undersaturation, alkalinity and calcium content: basalts/basanites, olivine nephelinites and olivine melilitites (Fig. 5). Most of the nephelinites and olivine melilitites are gathered in the foidite field in the TAS diagram (Fig. 4). In general, silica-undersaturation increases from north central lavas to south shield lavas through northwest shield lavas (Fig. 4). Eleven olivine nephelinites and the two olivine melilitites contain CIPW normative larnite (Nlarnite: $\mathrm{Ca}_{2} \mathrm{SiO}_{4}$ ), with contents higher than 10 $\%$ normative for olivine melilitites (Fig. 5), consistently with the criterion proposed by Wooley et al. (1996) to define this type of lavas. According to Médard et al. (2004), olivine melilitites can be considered as ultracalcic lavas $\left(\mathrm{CaO}>13.5 \mathrm{wt} . \%\right.$ and $\mathrm{CaO} / \mathrm{Al}_{2} \mathrm{O}_{3}>1$ wt.\%). Plots of $\mathrm{CaO}, \mathrm{Al}_{2} \mathrm{O}_{3}, \mathrm{~K}_{2} \mathrm{O}$, and $\mathrm{P}_{2} \mathrm{O}_{5}$ against $\mathrm{MgO}$ are shown in figure $6 . \mathrm{CaO}$ is positively correlated with $\mathrm{MgO}$ for lavas with $\mathrm{MgO}<8 \mathrm{wt} \%$. The ${ }_{\mathrm{N}}$ larnite samples and the mafic xenolith PN5b of Petite Terre have the highest $\mathrm{CaO}$ contents (> 12 wt. \%). The (tephri)phonolites of the Combani massif form a low-CaO trend together with the lavas of the north central zone. $\mathrm{Al}_{2} \mathrm{O}_{3}$ and $\mathrm{K}_{2} \mathrm{O}$ display remarkable negative correlations with $\mathrm{MgO}$. 
299 Except for the $\mathrm{P}_{2} \mathrm{O}_{5}$-rich $\mathrm{N}$ larnite-bearing lavas, $\mathrm{P}_{2} \mathrm{O}_{5}$ increases with decreasing $\mathrm{MgO}$ up to $300 \mathrm{MgO} \sim 5 \mathrm{wt} . \%$, then decreases.

301

\subsection{Trace elements}

303

We investigate in Figs. 6e-h the chemical distinction of the volcanic domains using incompatible trace element variations against $\mathrm{Th}$.

(1) The post-shield lavas of the north central domain form linear trends versus Th.

They are distributed in two groups with different Th concentrations and variable contents on

$\mathrm{Nb}, \mathrm{Hf}$, and $\mathrm{Yb}$. These samples have the lowest $\mathrm{Nb} / \mathrm{Zr}$ ratios of the collection, displaying a decreasing trend with increasing Th.

(2) The recent phonolitic pumices of Petite Terre have the highest $\mathrm{Nb}, \mathrm{Hf}$, and $\mathrm{Yb}$ contents. Their $\mathrm{Nb} / \mathrm{Zr}$ values range from 0.25 to 0.27 .

(3) Most of the south domain samples plot linearly on the trace variation diagrams.

313 Most of the corresponding lavas are contemporaneous with the shield phase. The trend has a

314 slope especially low in the Hf versus Th diagram of figure 6f. The south domain samples are 315 scattered in the $\mathrm{Nb} / \mathrm{Zr}$ versus Th diagram of figure $6 \mathrm{~h}$.

(4) Amongst the south domain samples, the figure 6 diagrams can be used to

317 discriminate four lavas, all of them located in the post-shield Combani massif. They plot apart 318 in both $\mathrm{Nb}$ and Hf vs. Th diagrams (Fig. 6e and f), together with the Petite Terre pumices,. (5) The northwest domain, mainly constituted of shield mafic lavas, cannot be easily 320 distinguished in the figure 6 trace diagrams. The corresponding lavas plot either in the north 321 central trend (Fig. 6a and f) or with the southern samples (Fig. 6e and g). Post-shield olivine melilitites M66 and FL386, presented above, belong to this domain. 
Mafic samples (alkali basalts, basanites, olivine nephelinites and olivine melilitites) from Mayotte are enriched in light and middle REE (LREE and MREE, respectively) with respect to heavy REE (HREE), consistently with their OIB characteristics (Fig. 7a). Slope of the REE patterns increases from basalts/basanites to olivine nephelinites and to olivine melilitites. These latter are also slightly more enriched in middle MREE. In the primitive mantle-normalized multi-element diagram (Fig. 7b), patterns of the mafic lavas are bell shaped, as expected for OIB, and show strong negative anomalies in $\mathrm{Rb}, \mathrm{K}$ and $\mathrm{Pb}$, and, to a lesser extent, in U and Ti. Olivine melititites - especially FL 386 - display high values in U, Sr, P, Nd, Sm, Eu and Gd. Olivine-free nephelinites have, on average, higher REE contents than the mafic rocks (Fig. 7c). Phonolites have characteristic concave-up REE patterns, with low MREE values, and LREE and HREE compositions close to those of mafic and intermediate rocks. The pumices of Petite Terre, which have the highest REE contents amongst the phonolites, show a negative anomaly in Eu. Olivine-free nephelinites and all evolved rocks display negative anomalies in P and Ti (Fig. 7d). Moreover, phonolites (lavas and pumices) are depleted in $\mathrm{Ba}$ and phonolitic pumices also in $\mathrm{Sr}$.

\subsection{Isotopes}

A selection of $\mathrm{Sr}$ and $\mathrm{Nd}$ isotopic ratios and all the $\mathrm{Pb}$ data are given in Table 3 . In the ${ }^{207} \mathrm{~Pb} /{ }^{204} \mathrm{~Pb}$ vs. ${ }^{206} \mathrm{~Pb} /{ }^{204} \mathrm{~Pb}$ diagram of Figure $8 \mathrm{a}$, there are evident relationships between the isotopic compositions of the samples and their geographic location and age. In fact, most of the lavas from the south and northwest shield volcanoes exhibit the most radiogenic ${ }^{207} \mathrm{~Pb} /{ }^{204} \mathrm{~Pb}(>15.64)$ and ${ }^{206} \mathrm{~Pb} /{ }^{204} \mathrm{~Pb}(>19.87)$, whereas the post-shield north central domain lavas display the lowest ratios $\left({ }^{207} \mathrm{~Pb} /{ }^{204} \mathrm{~Pb}<15.6\right.$ and $\left.{ }^{206} \mathrm{~Pb} /{ }^{204} \mathrm{~Pb}<19.35\right)$. The post-shield Combani lavas, northwest olivine melititites, and Petite Terre samples (xenolith PN5b apart) 
348 show isotope ratios between these two groups but closer to north central lavas. This isotopic

349 distribution seems to roughly reflect the volcanological history of the island. In general, lavas 350 showing the most radiogenic $\mathrm{Pb}$ ratios have been sampled in the oldest parts of the island (> $3513.0 \mathrm{Ma}$ ), whereas the other samples belong to formations having an age $<\sim 2.5 \mathrm{Ma}$. The only 352 exceptions are the HIMU-flavored M25 and DMM-like M137 lavas, samples respectively 353 dated to 2.0 and 5.0 Ma but for which no plateau age could be calculated (Table 1). There is 354 also an uncertainty about the olivine melilitites (M66 and FL386), the age of which ranges 355 from 4.0 to $<1.0$ Ma. Even if the variations in the ${ }^{143} \mathrm{Nd} /{ }^{144} \mathrm{Nd} v \mathrm{vs} .{ }^{206} \mathrm{~Pb} /{ }^{204} \mathrm{~Pb}$ diagram are less 356 contrasted, similar trends can be observed. The ${ }^{143} \mathrm{Nd} /{ }^{144} \mathrm{Nd}$ ratios of the rocks from the shield 357 volcanoes, highly radiogenic in $\mathrm{Pb}$, are more scattered and in average lower than those of the 358 other samples. The ${ }^{87} \mathrm{Sr} /{ }^{86} \mathrm{Sr}$ ratio is less discriminative (Table 3).

359 When compared to other Comores Islands and mantle end-member (Depleted MORB-

360 Mantle: DMM; high ${ }^{238} \mathrm{U} /{ }^{204} \mathrm{~Pb}$ : HIMU; Enriched Mantle: EM1 and 2, of Zindler and Hart, 361 1986) isotope compositions, the most recent lavas from Mayotte tend towards the depleted 362 mantle, such as all the lavas produced by the La Grille volcano in Grande Comore and two 363 samples from Moheli. In contrast, samples collected in the south and northwest shield

364 volcanoes have a clear HIMU affinity, such as one sample from Moheli and all the lavas from 365 Anjouan that have been analyzed for $\mathrm{Pb}$ isotopes.

366 The south alkali basalt M41, that spatially belongs to south group but that shows less 367 silica-undersaturated composition, displays a Sr-Nd composition close to that of the Karthala 368 volcano in Grande Comore, which tends toward the EM end-members (Table 3): its $369{ }^{143} \mathrm{Nd} /{ }^{144} \mathrm{Nd}$ ratio is low $(0.51272)$ and its ${ }^{87} \mathrm{Sr} /{ }^{86} \mathrm{Sr}$ ratio especially high $(0.70383)$. M41 is 370 relatively fresh (LOI=1.1) and it has low $\mathrm{Rb} / \mathrm{Sr}$ ratio (0.5) suggesting that its high ${ }^{87} \mathrm{Sr} /{ }^{86} \mathrm{Sr}$ 371 ratio is a pristine characteristic. M41 sample has not been analyzed for Pb isotopes. As EM- 
372 like composition is restricted to this sample in Mayotte, sampling date and location have been

373 thoroughly checked and confirm the expression of EM mantle component in Mayotte.

374

\subsection{Spatial and temporal distribution of the geochemical characteristics}

The lavas from the main building phase of the shield volcanoes (south and northwest domains) have more radiogenic $\mathrm{Pb}$ compositions than the post-shield rocks (Combani massif, north central domains and Petite Terre).

$\underline{\text { Shield units }}$

The lavas from the south shield are among the highest silica-undersaturated of the 382 island (Fig. 4) including olivine-bearing and olivine-free nephelinites, basanites and 383 phonolites. They have the highest $\mathrm{CaO}$ contents together with the northwestern melilitites 384 (Fig. 6a), and include most of the ${ }_{N}$ larnite samples (Table 2). The south shield lavas have a HIMU affinity, with high $\mathrm{Pb}$ isotope ratios (Fig. 8).

Most of the analyzed samples from the northwest shield are moderately silicaundersaturated mafic lavas, mainly basanites, with characteristic low incompatible trace element contents. They show a HIMU affinity (Fig. 8). The basanitic xenolith PN5b from Petite Terre (Table 2) shares the trace and isotopic signature of the northwest shield lavas. These features suggest that this sample could correspond to a lava from the northwest shield

391 substratum, extracted during an explosive event and incorporated within the pumices.

\section{$392 \quad$ Post-shield units}

The only olivine melilitites of Mayotte are emplaced in the northwest domain during a post-shield extensional phase.

The post-shield lavas from the north central domain are moderately silica- 
397 from basalts/basanites to phonolites through tephrite/tephriphonolites (Fig. 6). All the

398 petrological types have a similar isotopic composition (e.g., $\mathrm{Nd}$ isotope ratios ranging from 3990.51288 to 0.51290 , Fig. 8 b). Such features suggest that chemical variations in north central 400 lavas reflect differentiation processes from melts generated from a rather homogeneous

401 mantle source, more depleted than for the other lavas.

402 The Combani evolved samples follow the highly silica-understurated trend in the TAS 403 diagram (Fig. 4). They have, however, lower $\mathrm{CaO}$ with respect to highly silica-undersaturated 404 intermediate and felsic lavas of the south domain (Fig. 6a). Both groups have also similar 405 behavior in HREE vs. Th diagrams (Fig. $6 \mathrm{~g}$ and Table 2), reflecting probably comparable 406 modalities of crystal fractionation. However, the Combani lavas are close to those of the north 407 central domain in Hf vs. Th (Fig. 6f) and they have specific high Nb contents (Fig. 6e). 408 Amongst the post-shield lavas, they have the most radiogenic ${ }^{206} \mathrm{~Pb} /{ }^{204} \mathrm{~Pb}$ values (Fig. 8). The pumices of Petite Terre are phonolitic in composition. They belong to the moderately silica-undersaturated trend in the TAS diagram (Fig. 4) and plot in a restricted 411 area of the trace element diagrams (Fig. 6e-g), away from all the other Mayotte samples.

\section{Discussion}

\subsection{Olivine melilitite genesis}

The olivine melilitites are ultracalcic mafic lavas, characterized by high contents in

$418 \mathrm{CaO}$ and $\mathrm{MgO}$; high silica-undersaturation, with $\mathrm{SiO}_{2}$ contents $<40$ wt.\% (Wilson et al., 419 1995); low values in $\mathrm{Al}_{2} \mathrm{O}_{3}$, and, to a lesser extent, alkalis; and straight slopes in chondrite420 normalized REE diagrams (Brey, 1978; Rogers et al., 1992; Wilson et al., 1995). Based on 421 such chemical features, Brey (1978) and Rogers et al. (1992) have proposed that melilititic 
422

423

424

425

426

427

428

432

primary magmas are generated by very low degree of partial melting of a garnet- (and phlogopite-?) bearing $\mathrm{CO}_{2}$-rich mantle source. Such low partial melting models for melilititic melts are consistent with the experimental works of Gudfinnsson and Presnall (2005). Wilson et al. (1995) and Melluso et al. (2011) have suggested that carbonates (probably dolomite) were involved in the melting process. From data of experimental petrology, Gudfinnsson and Presnall (2005) have positioned the field of the mantle at the origin of melilititic primary melts in the domain of garnet stability, in presence of $\mathrm{CO}_{2}$, at pressures ranging from 3 and 4 $\mathrm{GPa}$. Partial melting experiments of carbonated peridotite at $3 \mathrm{GPa}$ generate melt compositions close to melilititic lavas (Hirose, 1997; Dasgupta et al., 2007), except for $\mathrm{TiO}_{2}$ and $\mathrm{FeO}^{\mathrm{T}}$, lower in these experimental melts than in natural olivine melilitites. To account for their geochemistry, Dasgupta et al. $(2006,2007)$ propose as melting source a carbonated peridotite metasomatized by pyroxenitic melts.

Besides the wide range of geochemical features listed above, the olivine melilitites of Mayotte present specific characteristics, namely high $\mathrm{P}_{2} \mathrm{O}_{5}$ and $\mathrm{Sr}$ contents (Figs. 6d and 7b, and Table 2), and relative enrichments in MREE with respect to the other mafic rocks (Fig. 7a). The sole other mention of P-rich melilitites has been made by Bailey et al. (2005) for Ugandan rocks. In the figure $6 \mathrm{~d}$ diagram, it is shown that all the ${ }_{N}$ larnite samples are enriched in $\mathrm{P}_{2} \mathrm{O}_{5}$. Consequently, to explore the melilititic character of the P-rich ${ }_{\mathrm{N}}$ larnite lavas, we have reported them in the $\mathrm{P}_{2} \mathrm{O}_{5}$ vs. $\mathrm{CaO} /\left(\mathrm{SiO}_{2}+\mathrm{Al}_{2} \mathrm{O}_{3}\right)$ diagram of figure 9: the higher this ratio is, the more silica-undersaturated, $\mathrm{CaO}$-rich and $\mathrm{Al}_{2} \mathrm{O}_{3}$-poor the rock is. The positive correlation demonstrates that a high $\mathrm{P}_{2} \mathrm{O}_{5}$ content is also a melilititic feature in Mayotte. The $\mathrm{P}_{2} \mathrm{O}_{5}$ enrichment of the Nlarnite lavas (Figs. 6d and 9), together with the relatively high $\mathrm{Sr}$ and MREE contents of both olivine melilitites (Table 2 and Fig. 7), is consistent with the hypothesis of an apatite contribution in the genesis of these lavas. Apatite can be involved through two mechanisms: (1) melting at very low degree of apatite-bearing pyroxenite veins 
447 in lithospheric metasomatized mantle (Foley, 1992); (2) assimilation of apatite-bearing veins

448 during the ascent of primary melts formed at a greater depth (Bailey et al., 2005). Scenario

449 (1), implying small melting degrees, is consistent with the high silica-undersaturation of the 450 Nlarnite lavas, especially olivine melilitites. Both models imply a metasomatism episode, in 451 which $\mathrm{CO}_{2}$-rich fluids or carbonatitic melts are probably involved (Hirschmann et al., 2003).

452 This is consistent with the classic models of melilitite genesis (see references above) and with 453 the occurrence in Grande Comore lavas of mantle xenoliths metasomatized by alkali454 carbonatitic melt (Coltorti et al., 1999).

\subsection{HIMU-flavored lavas}

457

In order to minimize the effects of melt differentiation (crystallization, contamination) and to discuss the contribution of the mantle sources, this section focuses on relatively mafic lavas $(\mathrm{MgO}>5 \mathrm{wt} . \%)$. As evidenced in Figure 8, the isotopic composition of Mayotte lavas is consistent with mixing between depleted mantle and HIMU components.

The HIMU-flavored mafic lavas, characterized by high $\mathrm{Pb}$ isotopic ratios, are reputed to be enriched in $\mathrm{Nb}$ and $\mathrm{Ta}$ and depleted in alkali/earth-alkali elements relative to the other incompatible trace elements (Dupuy et al., 1989; Willbold and Stracke, 2006). These features are noticeable in the HIMU-like olivine nephelinites collected in the south shield of Mayotte (Table 2 and Fig. 7b). Nevertheless, rocks from the northwest shield, which also have a clear HIMU isotopic signature, do not show these trace element features.

The HIMU mantle end-member is generally considered as the signature of a long-lived mantle reservoir $(>1 \mathrm{Ga})$. It has been ascribed to $(1)$ a metasomatized mantle that has undergone a removal of $\mathrm{Rb}$ and $\mathrm{Pb}$ (Zindler and Hart, 1986) and/or an U enrichment through $\mathrm{CO}_{2}$-rich fluids (Nakamura and Tatsumoto, 1988); (2) an ancient subduction-modified 
472

473

474

475

476

477

478

479

480

481

482

483

484

485

486

487

488

489

490

491

492

493

494

495

496

oceanic lithosphere, depleted in LILE as the result of dehydration (White and Hofmann, 1982;

Dupuy et al., 1989); or (3) combination of both models, i.e. a peridotite metasomatized with carbonated silicate melts, carbonatites derived from a recycled oceanic crust (Jackson and

Dasgupta, 2008) or carbonated eclogites (Dasgupta et al, 2010). The fact that the lavas from the northwest shield are not enriched in Ta and $\mathrm{Nb}$ (Table 2) is not really consistent with the model (2).

In Mayotte, only the oldest rocks show a HIMU signature. Contrary to some Marquesas examples as Ua Pou (Duncan et al., 1986; Legendre et al., 2005) and Eiao (Caroff et al., 1995), where the HIMU-like lavas have distinct petrographic and geochemical features compared to the other rocks, here, the isotopic composition is disconnected from the silicaundersaturation and elemental (major and trace elements) composition of the lavas, which precludes any connection between source composition and partial melting modalities.

The isotopic composition of Mayotte lavas is consistent with a mixing between DMM and HIMU end-members (Fig. 8). This feature has already been stated for the Canary Archipelago by Gurenko et al. (2009) and Aulinas et al. (2010). However, the HIMU-like lavas in Gran Canaria correspond to a post-shield phase (Aulinas et al., 2010), unlike Mayotte. Isotopic data for Canaries and Mayotte are both consistent with the assumption of small-scale HIMU heterogeneities in a depleted mantle (see section 7.3).

We compare the $\mathrm{Nd} / \mathrm{Yb}$ vs. $\mathrm{SiO}_{2}$ and $\mathrm{Nd} / \mathrm{Yb}$ vs. $\mathrm{Nb} / \mathrm{Zr}$ diagrams (Fig. 10) and the isotopic ratios (Fig. 8) in order to discriminate source composition, apatite contribution and melting degree. Apatite contribution during a deep metasomatism episode increases $\mathrm{Nb} / \mathrm{Yb}$ ratio at constant $\mathrm{Nb} / \mathrm{Zr}$ ratio and $\mathrm{SiO}_{2}$ content. Decrease of melting degree induces a decrease of $\mathrm{SiO}_{2}$ content and an increase of $\mathrm{Nd} / \mathrm{Yb}$ and $\mathrm{Nb} / \mathrm{Zr}$ ratios. From the data distribution in Figure 10, Nlarnite-bearing lavas would result from low partial melting degree of a metasomatized apatite-bearing mantle source, with (Nlarnite-bearing nephelinites) or without 
497 (olivine melilitites) HIMU affinity (Fig. 8). South and northwest shield lavas would derive

498 from a similar HIMU-like mantle source (Fig. 8) and their elemental distinction results from

499 increase of the partial melting degree from south to northwest lavas. North central post-shield

500 lavas derive from a more depleted mantle (Fig. 8), through higher melting degrees than lavas

501 of the main building stage (Fig. 10).

502

503 7.3. Genesis of Comores lavas

504

505

Two groups of mantle source models below Comores are proposed, which imply

506 interactions between melt issued (1) from an EM1-HIMU heterogeneous plume and a DMM

507 metasomatized lithosphere (Deniel, 1998); and (2) from a homogeneous plume with a

508 dominant EM1 signature and a DMM-HIMU metasomatized lithosphere (Class and

509 Goldstein, 1994, 1997; Späth et al., 1996; Class et al., 1998). In the latter models, the HIMU

510 component would be introduced in the Comorian mantle reservoir through delamination or

511 thermal erosion of a continental lithosphere during the Gondwana break-up. This group of

512 models is consistent with the geographic position of the Comores Archipelago between two

513 HIMU-bearing continental blocks: Africa and Madagascar (Bell and Tilton, 2001; Melluso et

514 al., 2011).

515 Our data are rather consistent with the second type of models for the mantle source

516 below Mayotte (Fig. 11): clear DMM-HIMU mixing and quasi absence of EM1 compositions

517 (except M41, Table 3). During the main building stage, partial melting of a DMM-HIMU

$518 \mathrm{CO}_{2}$-metasomatized lithosphere produced the south and northwest shield melts, with lower

519 partial melting degrees for the south lavas (Fig. 10). The melting processes occurred in the

520 garnet stability field, as suggested by the presence of ${ }_{N}$ larnite-bearing ultracalcic melts (Brey

521 and Green, 1977). During the post-shield phase, the more isotopically depleted homogeneous 
north central melts were formed through higher melting degrees. The other post-shield rocks have $\mathrm{Nd}$ and $\mathrm{Pb}$ isotopic features intermediate between this north central group and the lavas of the main building phase (Fig. 8). The progressive increase of the depleted component influence through time (Fig. 8), especially for the north central rocks (Fig. 10), can be related to a lower proportion of HIMU component in the mantle source or to a progressive dilution of the melts issued from fusible and small-sized HIMU heterogeneities when melt productivity increases. However, HIMU-flavored northwest lavas are produced by similar melting degrees as the depleted north central lavas. We thus propose that the isotopic signature of the postshield north central lavas is related to a high partial melting of a source where the HIMU component would have been partially consumed during the main building stage. The olivine melilitites would be generated from a source isotopically equivalent, but enriched in $\mathrm{CO}_{2}$ and $\mathrm{P}_{2} \mathrm{O}_{5}$ (probably with modal dolomite \pm apatite) and with a low degree of partial melting. The most plausible lithologies for generating the silica-undersatured primary melts of Mayotte lavas are carbonated garnet peridotite (Hirose, 1997; Dasgupta et al., 2007) and/or silicadeficient garnet pyroxenite/eclogite (Hirschmann et al., 2003, Dasgupta et al., 2010; Le Roux et al., 2011). Considering that the HIMU signature of the rocks is disconnected from partial melting modalities and that the Mayotte lavas, more or less fractionated, are not primary magmas, it would be difficult to go further in characterization of the source lithology. The model of a depleted lithospheric mantle with HIMU small-scale heterogeneities can be extended to the other islands of the Comores archipelago. Indeed, the mixing trend DMM-HIMU is clear for Moheli, Anjouan and "La Grille"-type lavas from Grande Comore (Fig. 8). Nevertheless, the "Karthala"-type recent lavas from Grande Comore show a specific EM1 signature $\left({ }^{87} \mathrm{Sr} /{ }^{86} \mathrm{Sr}>0.70350\right.$ and $\left.{ }^{143} \mathrm{Nd} /{ }^{144} \mathrm{Nd}<0.51275\right)$. Class et al (1998) argued that the "Karthala"-type lavas result from mixtures between plume and lithosphere melts. Thus, we propose that Comores lavas are mainly generated by partial melting of a DMM-HIMU 
$547 \mathrm{CO}_{2}$-metasomatized lithospheric mantle. The EM1 Comorian mantle plume would just have a

548 thermal effect, except for the "Karthala"-type lavas - and for the Mayotte basalt M41,

549 exhibiting an equivalent $\mathrm{Sr}-\mathrm{Nd}$ isotopic composition - which probably resulted from

550 plume/lithosphere interactions (Fig. 11).

\section{Concluding remarks}

553

The new set of geochronological and geochemical data presented in this study is used to discuss the chemistry and the mineralogy of the mantle source below Mayotte. The two main results are: (1) the characterization for the first time in the Comores of melilite-bearing lavas, including two olivine melilitites; and (2) the clear evidence of a HIMU signature in the shield lavas. Both features may or may not concern same samples.

Without doubt, the melting mantle source involved in the genesis of the Mayotte lavas is chemically and mineralogically heterogeneous at small scale. The HIMU affinity could find its origin in lithospheric components metasomatized by $\mathrm{CO}_{2}$-rich fluids, whereas melilitebearing lavas would derive from partial melting at very low degree of a mantle source, isotopically similar or not, bearing modal carbonate and apatite. Time-increasing partial melting during the main building phase of the shield volcanoes would favor the expression in the post-shield lavas of a more depleted mantle signature, as the consequence of the dilution of the HIMU heterogeneities in the mantle, maybe coupled with their partial consumption during the shield phase.

Petrological and geochemical data can thus be used to draw a composite picture of the mantle below Mayotte, which probably changes with time. Regardless of what lavas are concerned, the melting lithosphere below Mayotte presents a general characteristic feature, which reconciles both isotopic and mineralogical data: it has undergone $\mathrm{CO}_{2}$-metasomatism. 
573

574

575

576

577

578

579

580

581

582

583

584

585

586

587

588

589

590

591

592

593

594

595

\section{Acknowledgements}

Field studies were conducted in 2001 with the financial support of the Conseil

Régional de La Réunion and the Laboratoire GéoSciences Réunion, and in 2010 and 2011 with the financial and logistic support of the BRGM (Bureau de Recherches Géologiques et

Minières) and with the participation of F. Lacquement and J. Bernard. ISterre is part of Labex OSUG@2020 (ANR10 LABX56). The authors are grateful to J. Langlade and V. Batanova (microprobe analyses), C. Bollinger (ICP-MS Brest), Ph. Nonnotte (TI-MS), C. Liorzou (ICPAES), Y. Germain (MC-ICP-MS Ifremer), and P. Tiffenbach (thin sections). Detailed and constructive remarks by Drs Meritxell Aulinas and Hannes B. Mattsson helped us a lot to improve the manuscript. We also thank Dr Nelson Eby for his editorial assistance.

\section{Appendix. Supplementary Table S1.}

Supplementary data to this article can be found online at doi:

\section{References}

Arnaud, N., Tapponnier, P., Roger, F., Brunel, M., Scharer, U., Wen, C. and Zhiqin, X., 2003. Evidence for Mesozoic shear along the western Kunlun and Altyn-Tagh fault, northern Tibet (China). Journal of Geophysical Research, 108(B1), 2053, doi:10.1029/2001JB000904.

Audru, J.C., Guennoc, P., Thinon, I., Abellard, O., 2006. Bathymay: la structure sous-marine de Mayotte révélée par l'imagerie multifaisceaux. Compte Rendus Geoscience 338, $1240-1249$. 
Aulinas, M., Gimeno, D., Fernandez-Turiel, J.L., Font, L., Perez-Torrado, F.J., RodriguezGonzalez, A., Nowell, G.M., 2010. Small-scale mantle heterogeneity on the source of the Gran Canaria (Canary Islands) Pliocene-Quaternary magmas. Lithos 119, 377-392.

Barrat, J.-A., Keller, F., Amossé, J., Taylor, R.N., Nesbitt, R.W., Hirata, T., 1996.

Determination of rare earth elements in sixteen silicate reference samples by ICP-MS after Tm addition and ion exchange separation. Geostandards Newsletters 20, 133-139.

Barrat, J.-A., Zanda, B., Moynier, F., Bollinger, C., Liorzou, C., Bayon, G., 2012. Geochemistry of $\mathrm{CI}$ chondrites: Major and trace elements, and $\mathrm{Cu}$ and $\mathrm{Zn}$ isotopes. Geochimica et Cosmochimica Acta 83, 79-92.

Bailey, K., Lloyd, F., Kearns, S., Stoppa, F., Eby, N., Woolley, A., 2005. Melilitite at Fort Portal, Uganda. Another dimension of the carbonate volcanism. Lithos 85, 15-25.

Bell, K., Tilton, G.R., 2001. Nd, Pb and Sr isotopic compositions of East African carbonatites: evidence for mantle mixing and plume inhomogeneity. Journal of Petrology 42, 1927-1945.

Bertil, D., Regnoult, J.M., 1998. Seismotectonic of Madagascar. Tectonophysics 294, 57-74.

Brey, G., 1978. Origin of olivine melilitites - chemical and experimental constraints. Journal of Volcanology and Geothermal Research 3, 61-88.

Brey, G., Green, D.H., 1977. Systematic study of liquidus phase relations in olivine melilitite $+\mathrm{H}_{2} \mathrm{O}+\mathrm{CO}_{2}$ at high pressures and petrogenesis of an olivine melilitite magma. Contributions to Mineralogy and Petrology 61, 141-162.

Camoin, G.F., Montaggioni, L.F., Braithwaite, C.J.R., 2004. Late glacial to post glacial sea levels in the Western Ocean. Marine Geology 206, 119-146.

Caroff, M., Maury, R.C., Vidal., Ph., Guille, G., Dupuy, C., Cotten, J., Guillou, H., Gillot, P.Y., 1995. Rapid temporal changes in Ocean Island Basalt composition: evidence from a 800 m-deep drill hole in Eiao shield (Marquesas). Journal of Petrology 36, 1333-1365. 
621 Chauvel, C., Bureau, S., Poogi, C., 2011. Comprehensive chemical and isotopic analyses of 622 basalt and sediment reference materials. Geostandards and Geoanalytical Research. 35, $623 \quad 125-143$.

624 Class, C., Goldstein, S.L., 1994. Ocean island basalts and lithospheric melting: constraints 625 from the source mineralogy. V.M. Goldschmidt Conference, Edimburgh, Abstr. Vol., p. $626 \quad 175$.

627 Class, C., Goldstein, S.L., 1997. Plume-lithosphere interactions in the ocean basins: 628 constraints from the source mineralogy. Earth Planet. Sci. Lett. 150, 245-260.

629 Class, C., Goldstein, S.L., Altherr, R., Bachelery, P., 1998. The process of Plume 630 Lithosphere interactions in the Ocean Basins - The case of Grande Comore. Journal of $631 \quad$ Petrology 39, 881-903.

632 Class, C., Goldstein, S.L., Shirey, S.B., 2009. Osmium isotopes in Grande Comore lavas: a 633 new extreme among a spectrum of EM-type mantle endmembers. Earth and Planetary $634 \quad$ Science Letters 284, 219-227.

635 Class, C., Goldstein, S.L., Stute, M., Kurz, M., Schlosser, P., 2005. Grande Comore island: a 636 well-constrained low 3He/4He mantle plume. Earth and Planetary Science Letters 233, 637 391-409.

638 Coltorti, M., Bonadiman, C., Hinton, R.W., Siena, F., Upton, B.G.J., 1999. Carbonatite 639 metasomatism of the oceanic upper mantle: evidence from clinopyroxenes and glasses 640 in ultramafic xenoliths of Grande Comore, Indian Ocean. Journal of Petrology 40, 133$641 \quad 165$.

642 Cotten, J., Le Dez, A., Bau, M., Caroff, M., Maury, R.C., Dulski, P., Fourcade, S., Bohn, M., 643 Brousse, R., 1995. Origin of anomalous rare-earth elements and yttrium enrichments in 644 sub-aerially exposed basalts: evidence from French Polynesia. Chemical Geology 119, 645 115-138. 
646 Dasgupta, R., Hirschmann, M.M., Smith, N.D., 2007. Partial melting experiments of peridotite $+\mathrm{CO}_{2}$ at $3 \mathrm{GPa}$ and genesis of alkali ocean island basalts. Journal of Petrology 48, 2093-2124.

Dasgupta, R., Jackson, M.G., Lee, C.-T.A., 2010. Major element chemistry of ocean island basalts - Conditions of mantle melting and heterogeneity of mantle source. Earth and Planetary Science Letters 289, 377-392.

Dasgupta, R., Hirschmann, M.M., Stalker, K., 2006. Immiscible transition from carbonaterich to silicate-rich melts in the $3 \mathrm{GPa}$ melting interval of eclogite $+\mathrm{CO}_{2}$ and genesis of silica-undersaturated ocean island lavas. Journal of Petrology 47, 647-671.

Dautria, J.M., Dupuy, C., Takherist, D., Dostal, J., 1992. Carbonate metasomatism in the lithospheric mantle: peridotitic xenoliths from a melilititic district of the Sahara basin. Contributions to Mineralogy and Petrology 111, 37-52.

Dawson, J.B., 2012. Nephelinite-melilitite-carbonatite relationships: Evidence from Pleistocene-recent volcanism in northern Tanzania. Lithos 152, 3-10.

Debeuf, D., 2004. Etude de l'évolution volcano-structurale et magmatique de Mayotte (Archipel des Comores, Océan Indien). Thesis, University of La Réunion, 277 pp.

Deniel, 1998. Geochemical and isotopic ( $\mathrm{Sr}, \mathrm{Nd}, \mathrm{Pb}$ ) evidence for the plume-lithosphere interactions in the genesis of Grande Comore magmas (Indian Ocean). Chemical Geology 144, 281-303.

Duncan, R. A., McCulloch, M. T., Barsczus, H. G., Nelson, D. R., 1986. Plume vs lithospheric melts at Ua Pou, Marquesas Islands. Nature 322, 534-538. phenomena. Nature 303, 142-146. 
Dupuy, C., Barsczus, H.G., Dostal, J., Vidal, P., Liotard, J.M., 1989. Subducted and recycled lithosphere as the mantle source of ocean island basalts from southern Polynesia, central Pacific. Chemical Geology 77, 1-18.

Emerick, C.M., Duncan, R.A., 1982. Age progressive volcanism in the Comores Archipelago, western Indian Ocean and implications for Somali plate tectonics. Earth and Planetary Science Letters 60, 415-428.

Fleck, F.J., Sutter, J.F., Elliot, D.H., 1977. Interpretation of discordant ${ }^{40} \mathrm{Ar} /{ }^{39} \mathrm{Ar}$ age spectra of Mesozoic tholeiites from Antarctica. Geochimica et Cosmochimica Acta, 41, 15-32.

Foley, S., 1992. Vein-plus-wall-rock melting mechanisms in the lithosphere and the origin of potassic alkaline magmas. Lithos 28, 435-453.

Garcia, S., Arnaud, N.O., Angelier, J., Françoise, B., Homberg, C., 2003. Rift jump process in northern Iceland since $10 \mathrm{Ma}$ from ${ }^{40} \mathrm{Ar} /{ }^{39} \mathrm{Ar}$ geochronology. Earth and Planetary Science Letters 214, 529-544.

Gudfinnsson, G.H., Presnall, D.C., 2005. Continuous gradiations among primary carbonatitic, kimberlitic, melilititic, basaltic, picritic and komatiitic melts in equilibrium with garnet lherzolite at 3-8 GPa. Journal of Petrology 46, 1645-1659.

Gurenko, A.A., Sobolev, A.V., Hoernle, K.A., Hauff, F., Schmincke, H.-U., 2009. Enriched, HIMU-type peridotite and depleted recycled pyroxenite in the Canary plume: A mixedup mantle. Earth and Planetary Science Letters 277, 514-524.

Hajash, A., Armstrong, R.L., 1972. Paleomagnetic and radiometric evidence for the age of the Comores Islands, West Central Indian Ocean. Earth and Planetary Science Letters 16, 231-236.

Hirschmann, M.M., Kogiso, T., Baker, M.B., Stolper, E.M., 2003. Alkalic magmas generated by partial melting of garnet pyroxenite. Geology 31, 481-484. 
693 Hirose, K., 1997.Partial melt compositions of carbonated peridotite at $3 \mathrm{GPa}$ and role of $\mathrm{CO}_{2}$ 694 in alkali-basalt magma generation. Geophysical Research Letters 24 (22), 2837-2840.

695 Hoernle, K., Schmincke, H.-U., 1993. The petrology of the tholeiites through the melilite 696 nephelinites on Gran Canaria, Canary Islands: crystal fractionation, accumulation and 697 depths of melting. Journal of Petrology 34, 573-597.

698 Janney, P.E., Le Roex, A.P., Carlson, R.W., Viljoen, K.S., 2002. A chemical and multi699 isotope study of the Western Cape olivine melilitite province, South Africa: implications 700 for the sources of kimberlites and the origine of the HIMU signature in Africa. Journal $701 \quad$ of Petrology 43, 2339-2370.

702 Jackson, M.G., Dasgupta, R., 2008. Compositions of HIMU, EM1 and EM2 from global 703 704 trends between radiogenic isotopes and major elements in ocean island basalts. Earth

705 Le Bas, M.J., 1989. Nephelinitic and basanitic rocks. J. Petrol. 30, 1299-1313.

706 Le Bas, M.J., Le Maitre, R.W., Streckeisen, A., Zanettin, B., 1986. A chemical classification 707 708 of volcanic rocks based on the total alkali-silica diagram. Journal of Petrology 27, 745750.

Leclaire, L., Bassias, Y., Clocchiatti, M., Ségoufin, J., 1989. La ride de Davie dans le canal de Mozambique : approche stratigraphique et géodynamique. Comptes Rendus de l'Académie des Sciences, Paris 308, 1077-1089.

712 Legendre, C., Maury, R.C., Caroff, M., Guillou, H., Cotten, J., Chauvel, C., Bollinger, C., Hémond, C., Guille, G., Blais, S., Rossi, P., Savanier, D., 2005. Origin of exceptionally abundant phonolites on Ua Pou Island (Marquesas, French Polynesia): Partial melting of basanites followed by crustal contamination. Journal of Petrology 46, 1925-1962. 
716 Le Roux, V., Dasgupta, R., Lee, C.-T.A., 2011. Mineralogical heterogeneities in the Earth's mantle: Constraints from $\mathrm{Mn}, \mathrm{Co}, \mathrm{Ni}$ and $\mathrm{Zn}$ partitioning during partial melting. Earth and Planetary Science Letters 307, 395-408.

Maaløe, S., James, D., Smedley, P., Petersen, S., Grarmann, L.B., 1992. The Koloa volcanic suite of Kauai, Hawaii. Journal of Petrology 33, 761-784.

Malod, J.A., Mougenot, D., Raillard, S., Maillard, A., 1991. Nouvelles contraintes sur la cinématique de Madagascar : les structures de la chaîne de Davie. Comptes Rendus de 1'Académie des Sciences, Paris 312, 211-214.

Mattsson, H.B., Nandedkar, R.H.., Ulmer, P., 2013. Petrogenesis of the melititic and nephelinitic rock suites in the Lake Natron - Engaruka monogenetic volcanic field, northern Tanzania. Lithos 179, 175-192.

McDonough, W.F., Sun, S.-S., 1995. The composition of the Earth. Chemical Geology 120, $223-253$

Médard, E., Schmidt, M.W., Schiano, P., 2004. Liquidus surfaces of ultracalcic primitive melts: formation conditions and sources. Contributions to Mineralogy and Petrology $148,201-215$.

Melluso, L., Le Roex, A.P., Morra, V., 2011. Petrogenesis and Nd-, Pb-, Sr-isotope geochemistry of the Cenozoïc olivine melilitites and olivine nephelinites ("ankaratrites") in Madagascar. Lithos 127, 505-521.

Nakamura, Y., Tatsumoto, M., 1988. Pb, Nd and Sr isotopic evidence for a multi-component source for rocks of the Cook-Austral Islands and heterogeneities of mantle plumes. Geochimica et Cosmochimica Acta 52, 2909-2924.

Nehlig, P., Lacquement, F., Bernard, J., Caroff, M., Deparis, J., Jaouen, T., Pelleter, A.-A., Perrin, J., Prognon, C., Vittecoq, B., 2013. Notice de la carte géologique de Mayotte à 1/25 000, BRGM/RP-61803-FR. BRGM Éditions, Orléans. 
741 Nougier, J., Cantagrel, J.-M., Karche, J.P., 1986. The Comores archipelago in the western

742 Indian Ocean: volcanology, geochronology and geodynamic setting. Journal of African

$743 \quad$ Earth Sciences 5, 135-145.

744 Piqué, A., 1999. L'évolution géologique de Madagascar et la dislocation du Gondwana : une

745 introduction. Journal of African Earth Sciences 28 (4), 919-930.

746 Reisberg, L., Zindler, A., Marcantonio, F., White, W., Wyman, D., Weaver, B., 1993. Os

747 isotope systematics in ocean island basalts. Earth and Planetary Science Letters 120,

$748 \quad 149-167$.

749 Renne, .R., Swisher, C.C., Deino, A.L., Karner, D.b., Owens, T.1., DePaolo, D.J., 1998.

750 Intercalibration of standards, absolute ages and uncertainities in $\mathrm{Ar}^{40} / \mathrm{Ar}^{39}$ dating.

$751 \quad$ Chemical Geology 145, 117-152.

752 Roddick, J.C., Cliff, R.A., Rex, D.C., 1980. The evolution of excess argon in alpine biotitesan ${ }^{40} \mathrm{Ar}-{ }^{39} \mathrm{Ar}$ analysis. Earth and Planetary Science Letters 48, 185-208.

754 Rogers, N.W., Hawkesworth, C.J., Palacz, Z.A., 1992. Phlogopite in the generation of olivine-melilitites from Namaqualand, South Africa and implications for element fractionation processes in the upper mantle. Lithos 28, 347-365.

757 Salters, V.J.M., White, W.M., 1998. Isotope constraints on mantle evolution. Chemical Geology 145, 447-460.

759 Späth, A., Le Roex, A.P., Duncan, R.A., 1996. The geochemistry of lavas from the Comores Archipelago, western Indian Ocean: petrogenesis and mantle source region characteristics. Journal of Petrology 37 (4), 961-994.

762 Stieltjes, L., 1988. Notice explicative de la carte géologique de Mayotte à 1/50 000. BRGM 763 Éditions, Orléans. 
764 Suschevskaya, N.M., Kamenetsky, V.S., Belyatsky, B.V., Artamonov, A.V., 2013.

765

766

767

768

769

770

771

772

773

774

775

776

777

778

779

780

781

782

783

784

785

786

Figure captions 79.

Tindle, A.G., Webb, P.C., 1994. Probe-Amph-A spreadsheet program to classify microprobe derived amphibole analyses. Computer \& Geosciences 20 (7/8), 1201-1228.

White, W.M., Hofmann, A.W., 1982. Sr and Nd isotope geochemistry of oceanic basalts and mantle evolution. Nature 296, 821-825.

Willbold, M., Stracke, A., 2006. Trace element composition of mantle end-members : Implications for recycling of oceanic and upper and lower continental crust. Geochemistry Geophysics Geosystems 7, Q04004, doi : 10.1029/2005GC001005.

Wilson, M. Rosembaum, J.M., Dunworth, E.A., 1995. Melilitites: partial melts of the thermal boundary layer? Contributions to Mineralogy and Petrology 119, 181-196.

Wooley, A.R. et al., 1996. Classification of lamprophyres, lamproites, kimberlites and th kalsitic, melilitic and leucitic rocks. The Canadian Mineralogist 34, 175-186.

York, D., 1969. Least square fitting on a straight line with correlated errors, Earth and Planetary Science Letters 5, 320-324.

Zindler, A., Hart, S., 1986. Chemical geodynamics. Annual Review of Earth and Planetary Sciences $14,493-571$.

Zinke, J., Reijmer, J.J.G., Thomassin, B.A., 2003. Systems tracts sedimentology in the lagoon of Mayotte associated with the Holocene transgression. Sedimentary Geology 160, 57- 
788 Fig. 1. The Comores archipelago. K-Ar age ranges are indicated for each island: Grande

789 Comore (2 data by Hajash and Armstrong, 1972, and Emerick and Duncan, 1982); Moheli (12 790 data by Emerick and Duncan, 1982, and Nougier et al., 1986); Anjouan (8 data by Hajash and 791 Armstrong, 1972, Emerick and Duncan, 1982, and Nougier et al., 1986); Mayotte (34 data by 792 Hajash and Armstrong, 1972, Emerick and Duncan, 1982, and Nougier et al., 1986, and one 793 relative age determined by Zinke et al., 2003, for a pumice layer interbedded in the lagoon 794 stratigraphic succession). The value of 11.1 Ma of Anjouan corresponds to a remote value 795 measured on a syenitic xenolith. The Mayotte new age range of Table 1 is indicated in italic. 796 Inset: Mayotte in its geodynamical context.

797

798 Fig. 2. Geophysical and geological maps of Mayotte. (a) Bathymetry (from Audru et al., 799 2006). (b) Digital terrain model (DTM) of Mayotte (Nehlig et al., 2013); mounts: 1. Mlima 800 Dziani Bolé (472 m); 2. Mlima Digo (255 m); 3. Mlima Mtsapéré (572 m); 4. Mlima 801 Combani (477 m); 5. Mlima Bénara (660 m); 6. Mlima Choungui (594 m). (c) Geological 802 sketch of Mayotte, based on Debeuf (2004) and Nehlig et al. (2013); the main four domains 803 (south, northwest, north central, Petite Terre), limited by bold dashed lines, have been defined 804 from topographic, geochronological, petrographic and geochemical criteria; M\&I rocks: mafic 805 806 807

808 Fig. 3. Summary of petrographic data for Mayotte lavas: mineral occurrence and their 809 compositional range. NC: north central domain; Fo: forsterite; Wo: wollastonite; En: enstatite; 810 Ne: nepheline; An: anorthite; Or: orthoclase; Aegir.-augite: aegirine-augite; Fe-arfv.: ferro811 arfvedsonite; Fe-ecker.: ferro-eckermannite. Nomenclature of amphiboles based on Tindle 812 and Webb (1994). 
814 Fig. 4. Total alkali-silica (TAS) discrimination diagram for lavas and pumices from Mayotte

815 (weight percent). The fields are from Le Bas et al. (1986). For this diagram, major element

816 values were recalculated to $100 \%$ in a free water basis. The Combani samples (south domain)

817 are identified by a bold half circle.

818

819 Fig. 5. Nephelinite-melilitite-basanite classification diagram of Le Bas (1989) for mafic lavas

820 (MgO > 5 wt.\%) from Mayotte (weight percent). Inset: olivine melilitite-nephelinite

821 discrimination diagram of Wooley et al. (1996), same samples. Symbols as in figure 4.

822

823 Fig. 6. Variation of $\mathrm{CaO}, \mathrm{Al}_{2} \mathrm{O}_{3}, \mathrm{~K}_{2} \mathrm{O}$ and $\mathrm{P}_{2} \mathrm{O}_{5}$ vs. $\mathrm{MgO}$ (weight percent) and $\mathrm{Nb}, \mathrm{Hf}, \mathrm{Yb}$ and

$824 \mathrm{Nb} / \mathrm{Zr}$ vs. Th (ppm) for lavas and pumices from Mayotte. Symbols as in figure 4.

825

826 Fig. 7. Trace element patterns of representative Mayotte samples. (a) and (b): mafic lavas

$827(\mathrm{MgO}>5$ wt.\%); (c) and (d): intermediate nephelinites and phonolites. (a) and (c): chondrite-

828 normalized REE patterns (normalization values: Barrat et al., 2012); (b) and (d): primitive

829 mantle-normalized incompatible trace element patterns (normalization values: McDonough

830 and Sun, 1995).

831

832 Fig. 8. (a) ${ }^{143} \mathrm{Nd} /{ }^{144} \mathrm{Nd}$ vs. ${ }^{206} \mathrm{~Pb} /{ }^{204} \mathrm{~Pb}$ and (b) ${ }^{207} \mathrm{~Pb} /{ }^{204} \mathrm{~Pb}$ vs. ${ }^{206} \mathrm{~Pb} /{ }^{204} \mathrm{~Pb}$ isotope diagrams

833 showing Mayotte data compared with previously published data (Grande Comore: Dupré and

834 Allègre, 1983; Reisberg et al., 1993; Späth et al., 1996; Class and Goldstein, 1997; Class et

835 al., 1998; Deniel, 1998; Class et al., 2005; Class et al., 2009; Anjouan: Reisberg et al, 1993;

836 Salters and White, 1998; Moheli: Reisberg et al., 1993; Späth et al., 1996). The position of the 
837 DMM, EM I and II, and HIMU end-members are from Zindler and Hart (1986). Symbols as 838 in figure 4.

839

840 Fig. 9. $\mathrm{P}_{2} \mathrm{O}_{5}$ vs. $\mathrm{CaO} / \mathrm{SiO}_{2}$ (wt. \%) diagram for the ${ }_{\mathrm{N}}$ larnite lavas. Symbols as in figure 4.

842 Fig. 10. (a) $\mathrm{Nd} / \mathrm{Yb}$ (ppm) vs. $\mathrm{SiO}_{2}$ (wt. \%) and (b) $\mathrm{Nd} / \mathrm{Yb}$ vs. $\mathrm{Nb} / \mathrm{Zr}$ (ppm) diagrams for the

843 basic lavas from Mayotte. PM: partial melting. The grey areas correspond to HIMU-flavored 844 lava samples $\left({ }^{206} \mathrm{~Pb} /{ }^{204} \mathrm{~Pb}>19.87\right)$.

845

846 Fig. 11. Schematic model showing the mantle structure below Mayotte during its main

847 building phase. Partial melting of a DMM-HIMU $\mathrm{CO}_{2}$-metasomatized lithosphere produced 848 the south and northwest shield melts, with lower partial melting degrees for the south lavas.

849 The melting processes occurred in the garnet stability field.

850 


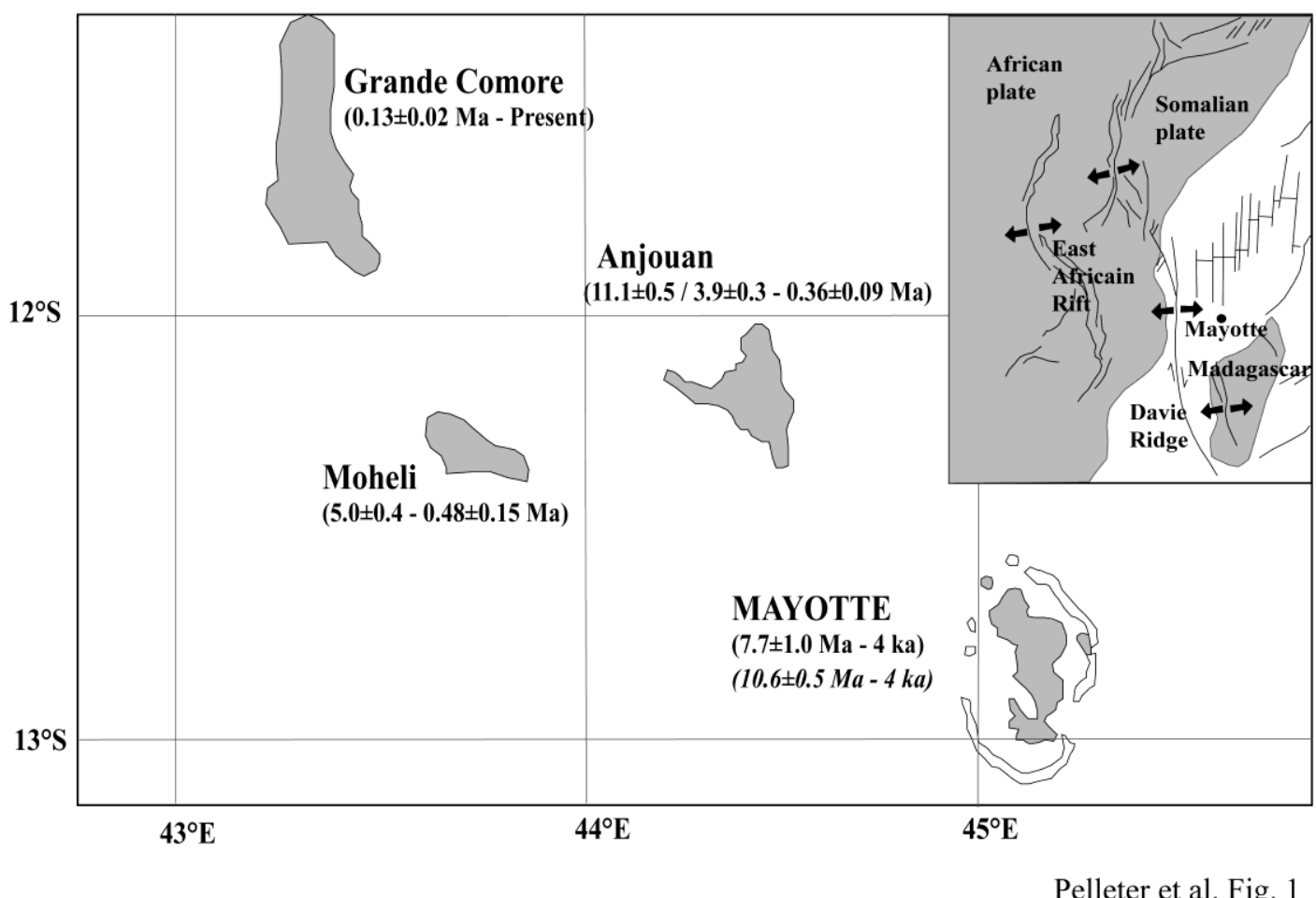

851 

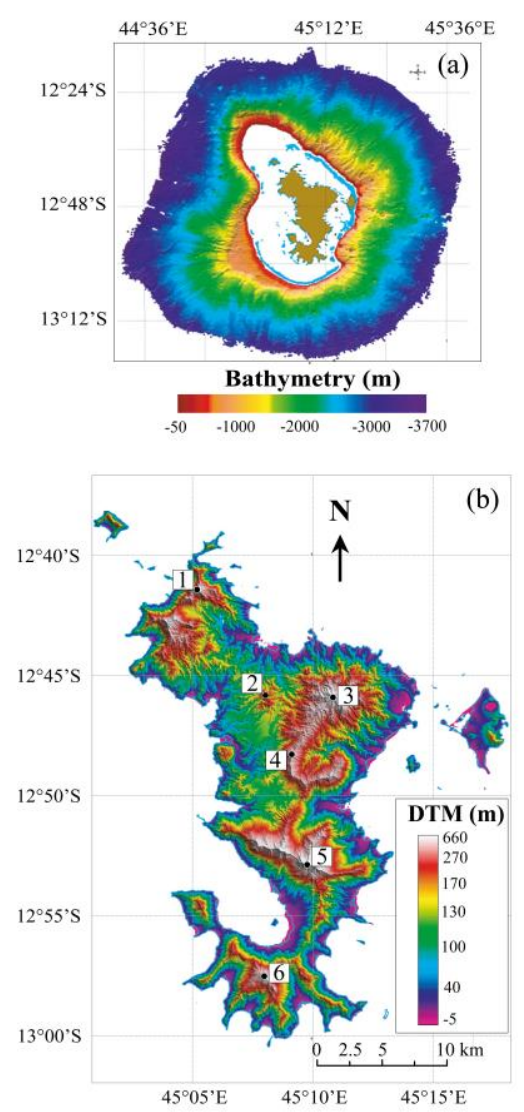

853
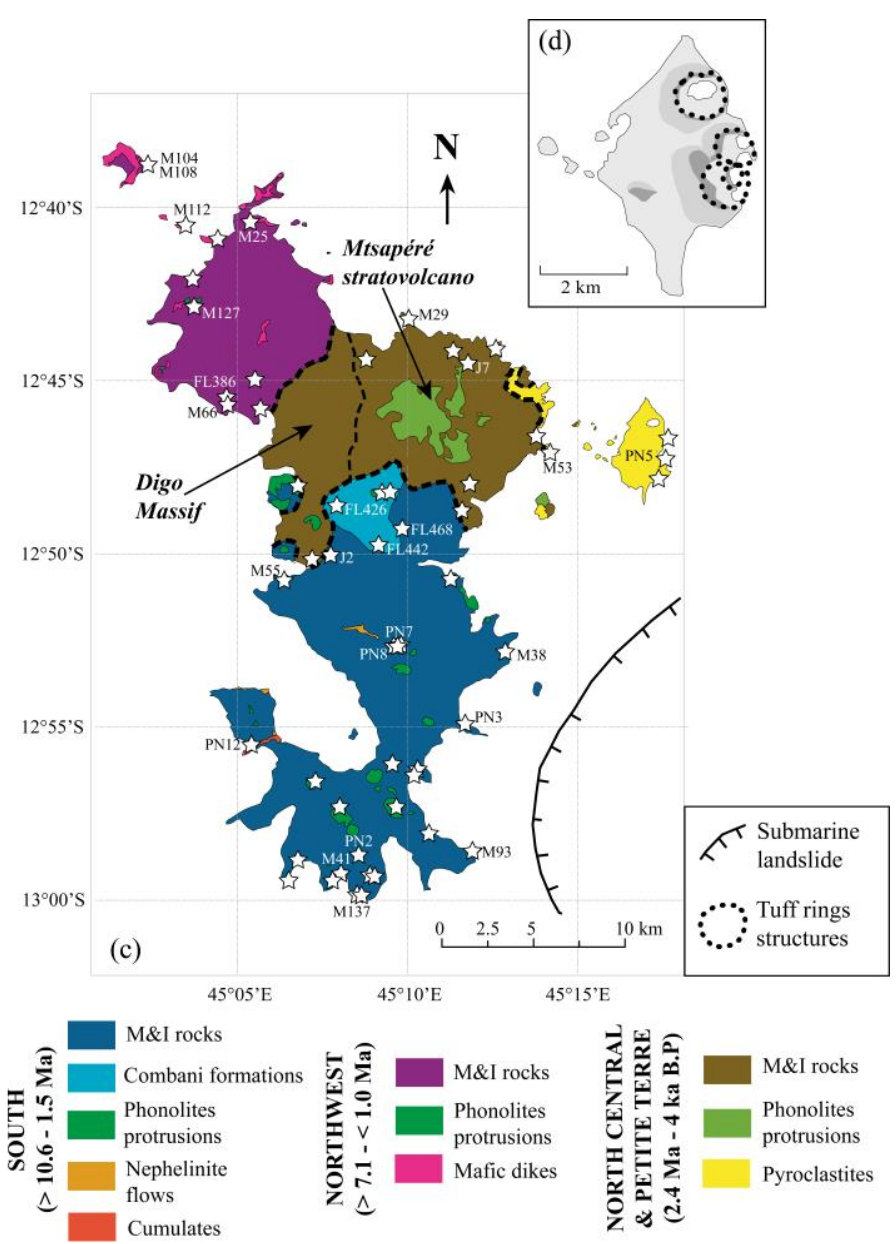

854 Fig. 2 


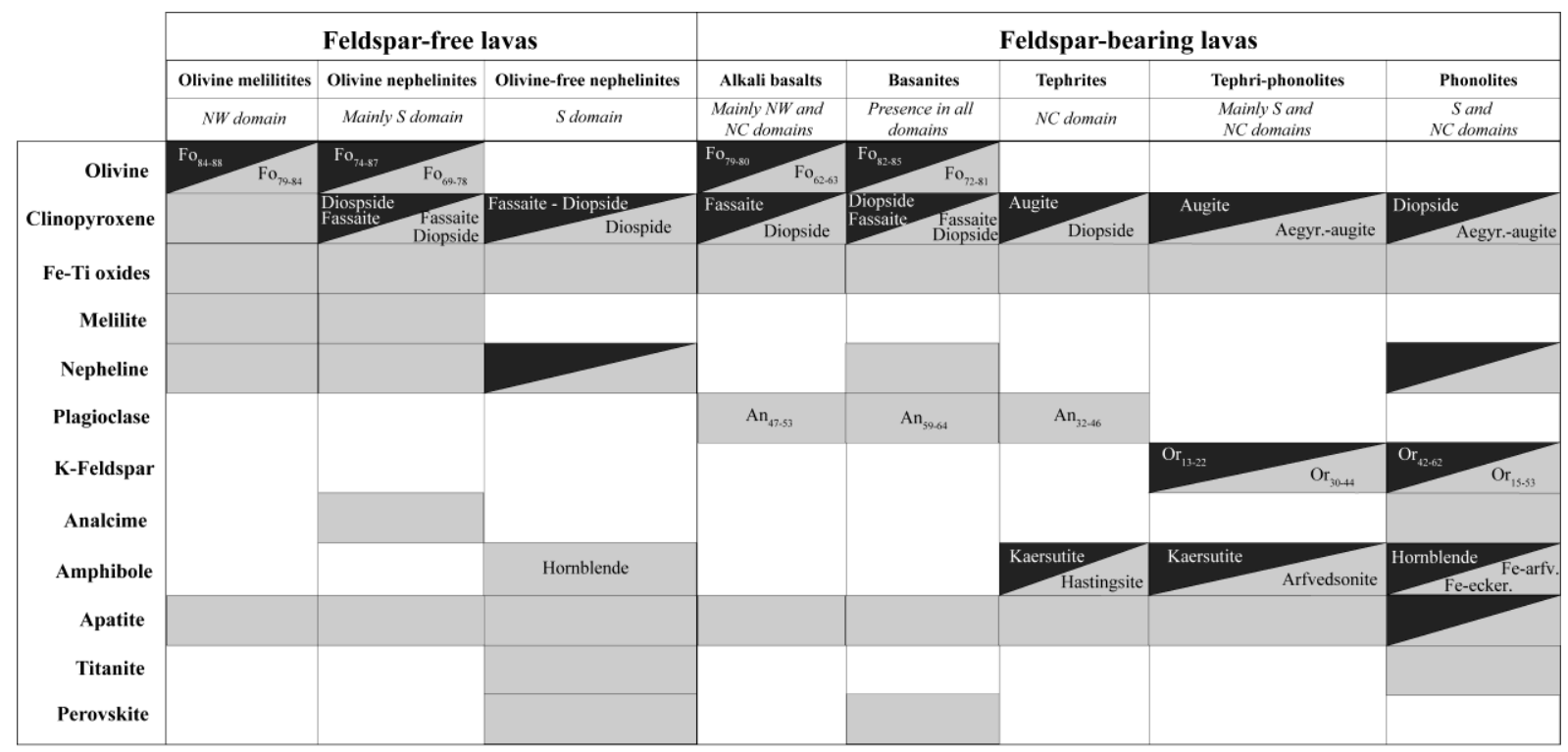

$856 \quad$ Fig. 3 


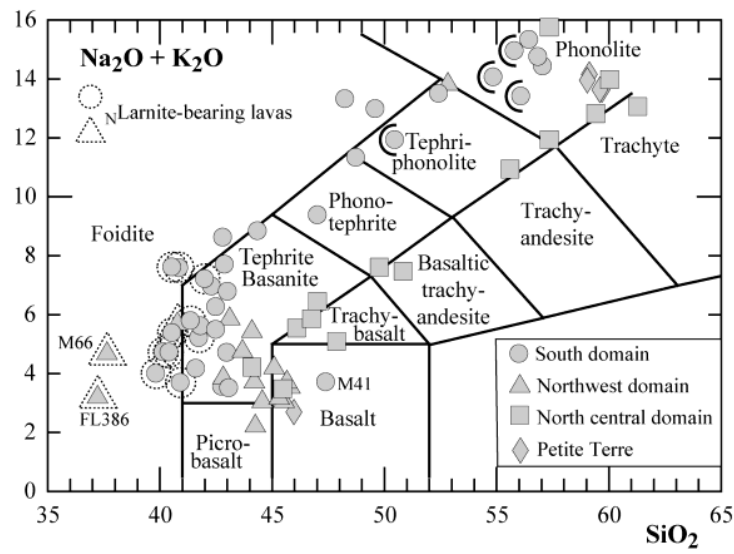

857

858

$859 \quad$ Fig. 4 


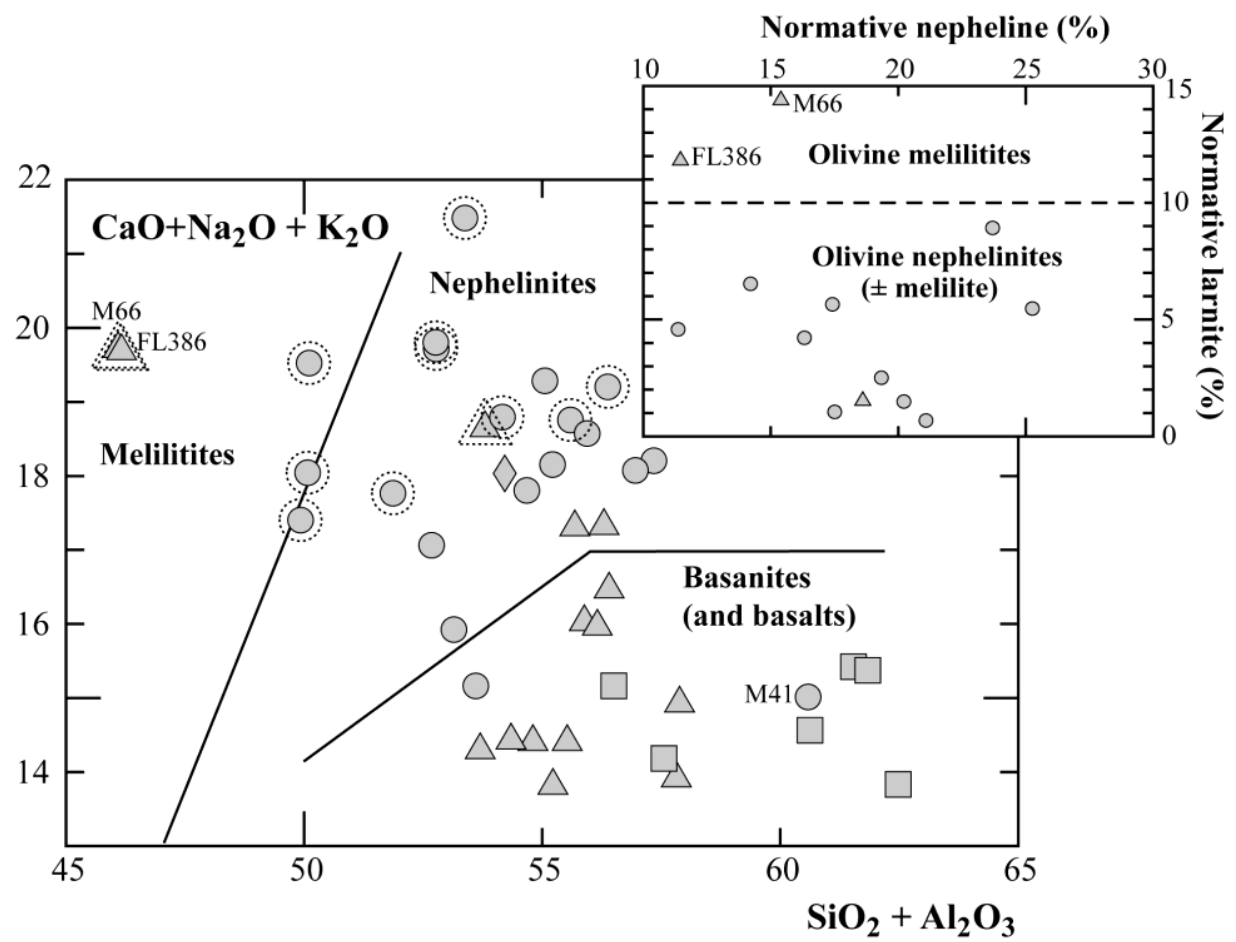

$861 \quad$ Fig. 5 


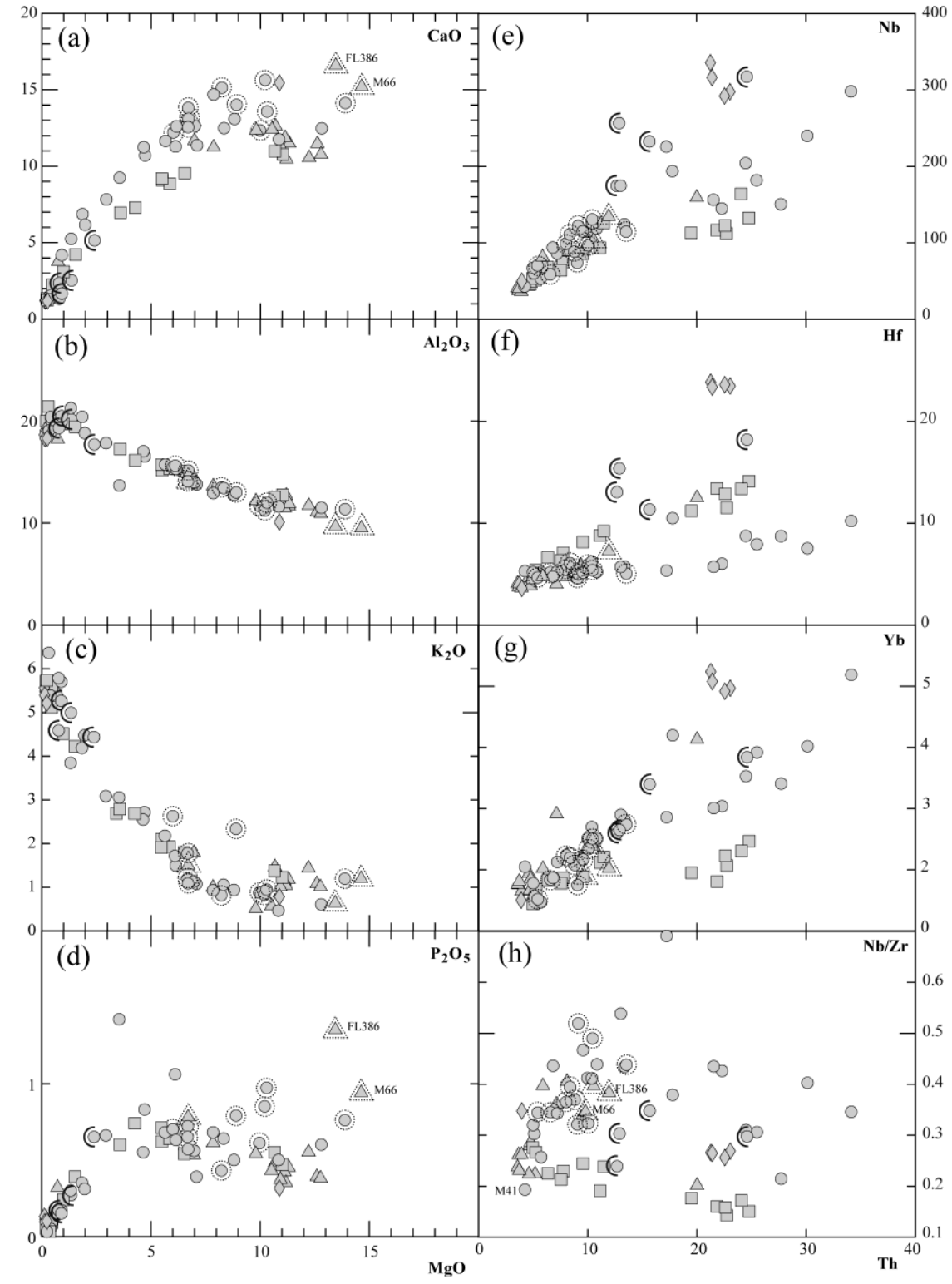

862

863 Fig. 6 

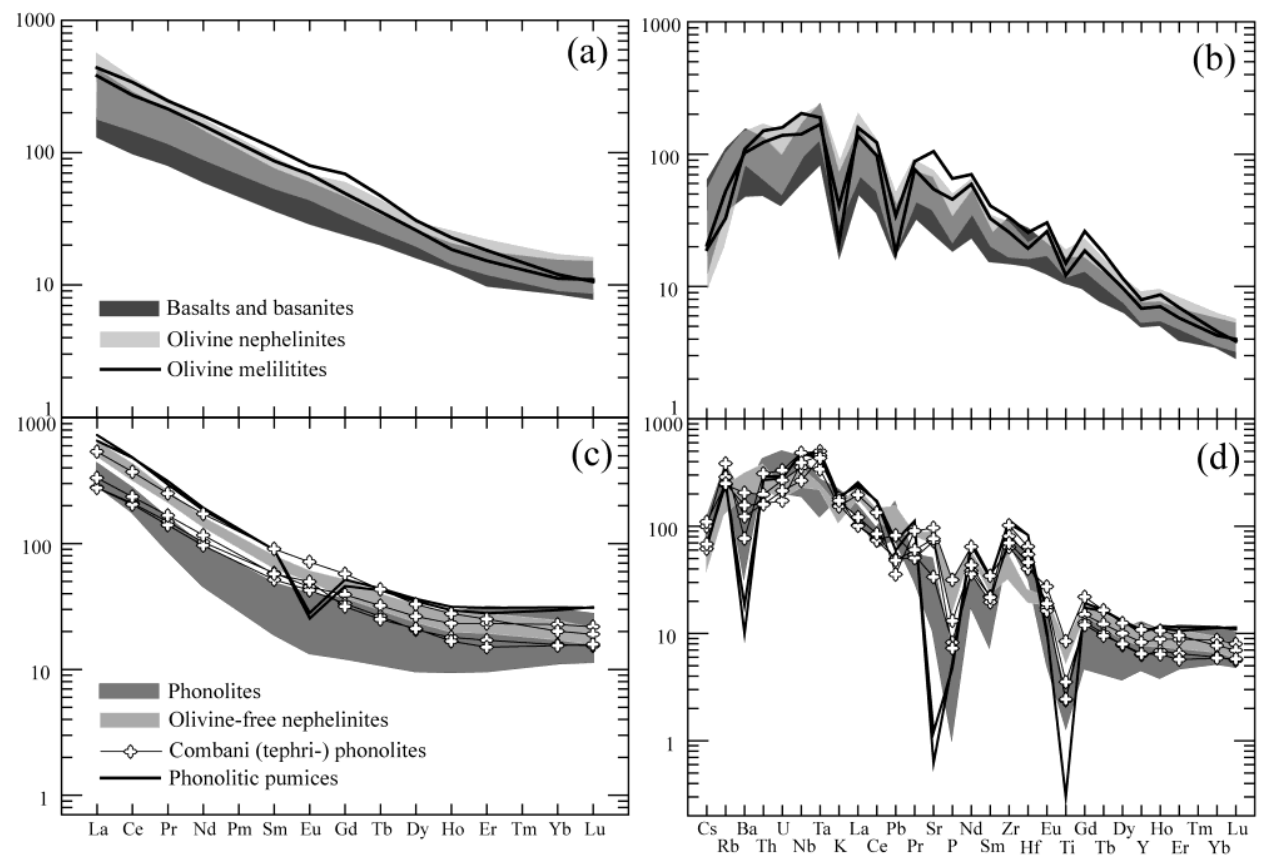

864

865

$866 \quad$ Fig. 7 


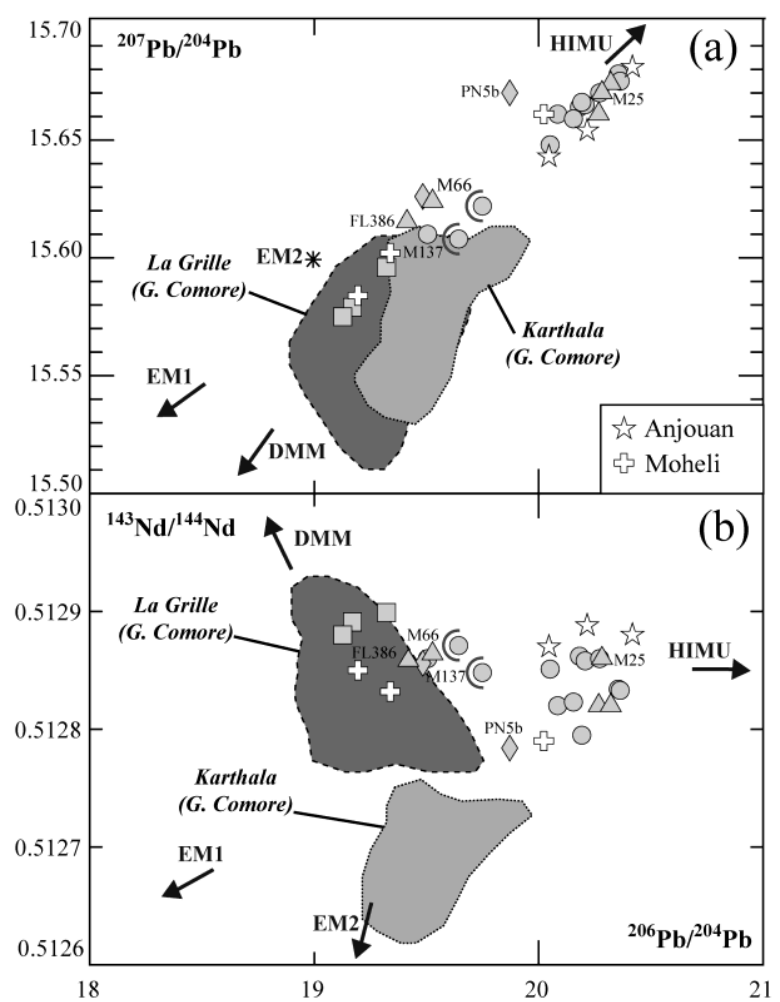

$868 \quad$ Fig. 8 


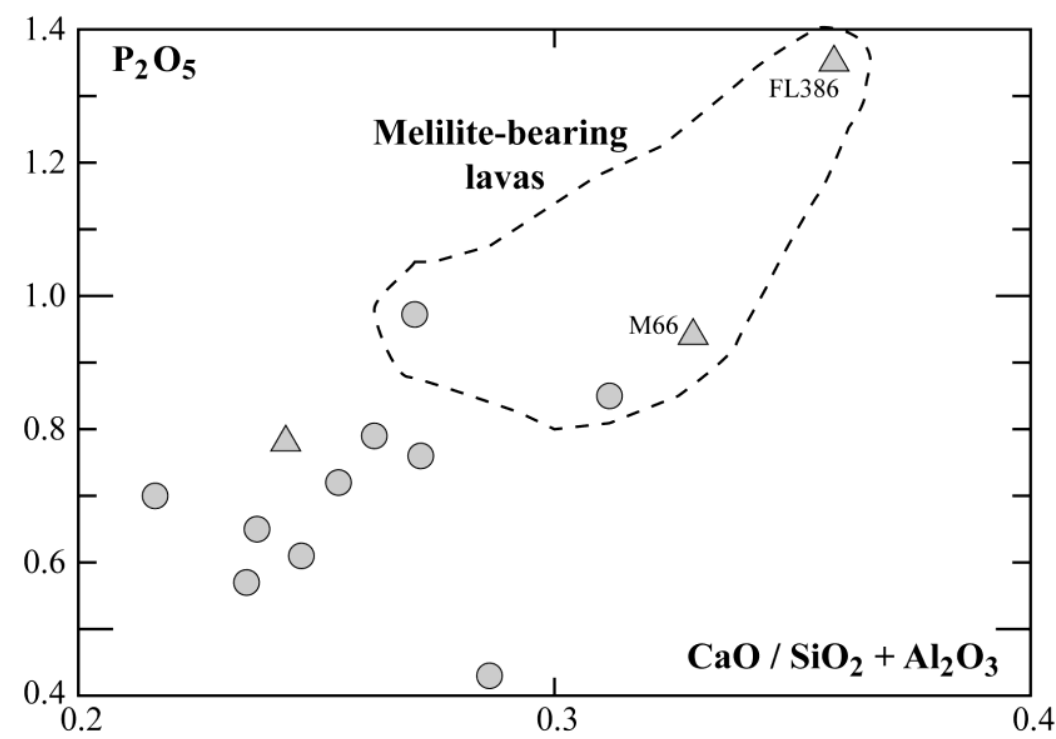

$871 \quad$ Fig. 9 


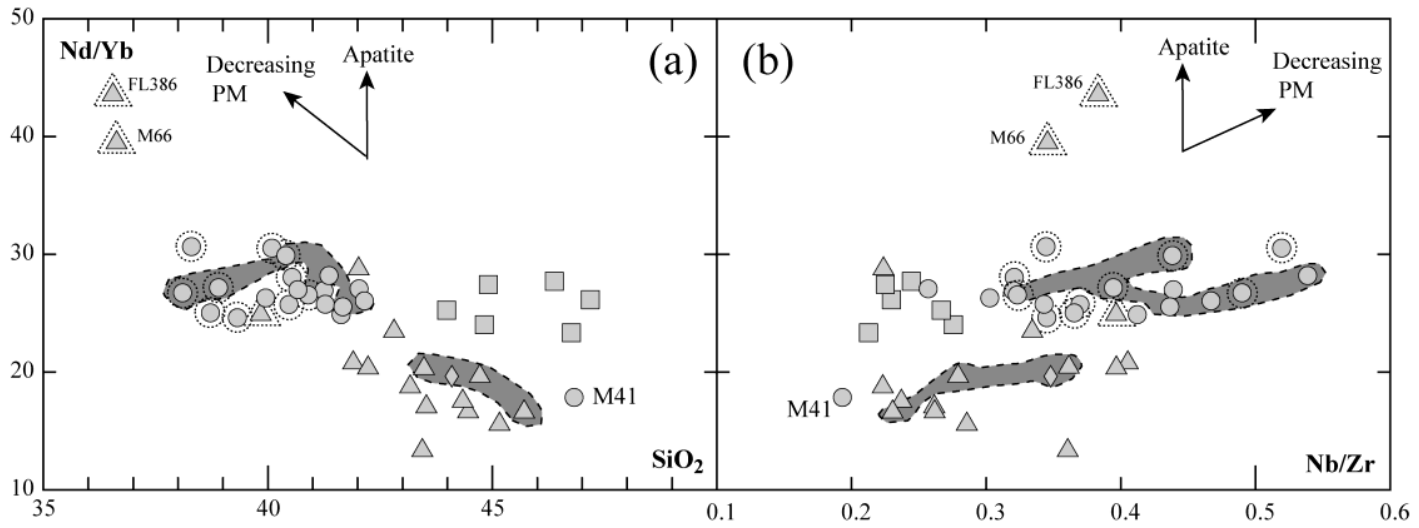

873 Fig. 10 


\section{Mayotte main building phase $(>10.6-\sim 3.0$ Ma)}

Northwest

shield
South

shield

N moderatly silica-undersatured highly silica-undersatured $\mathbf{S}$

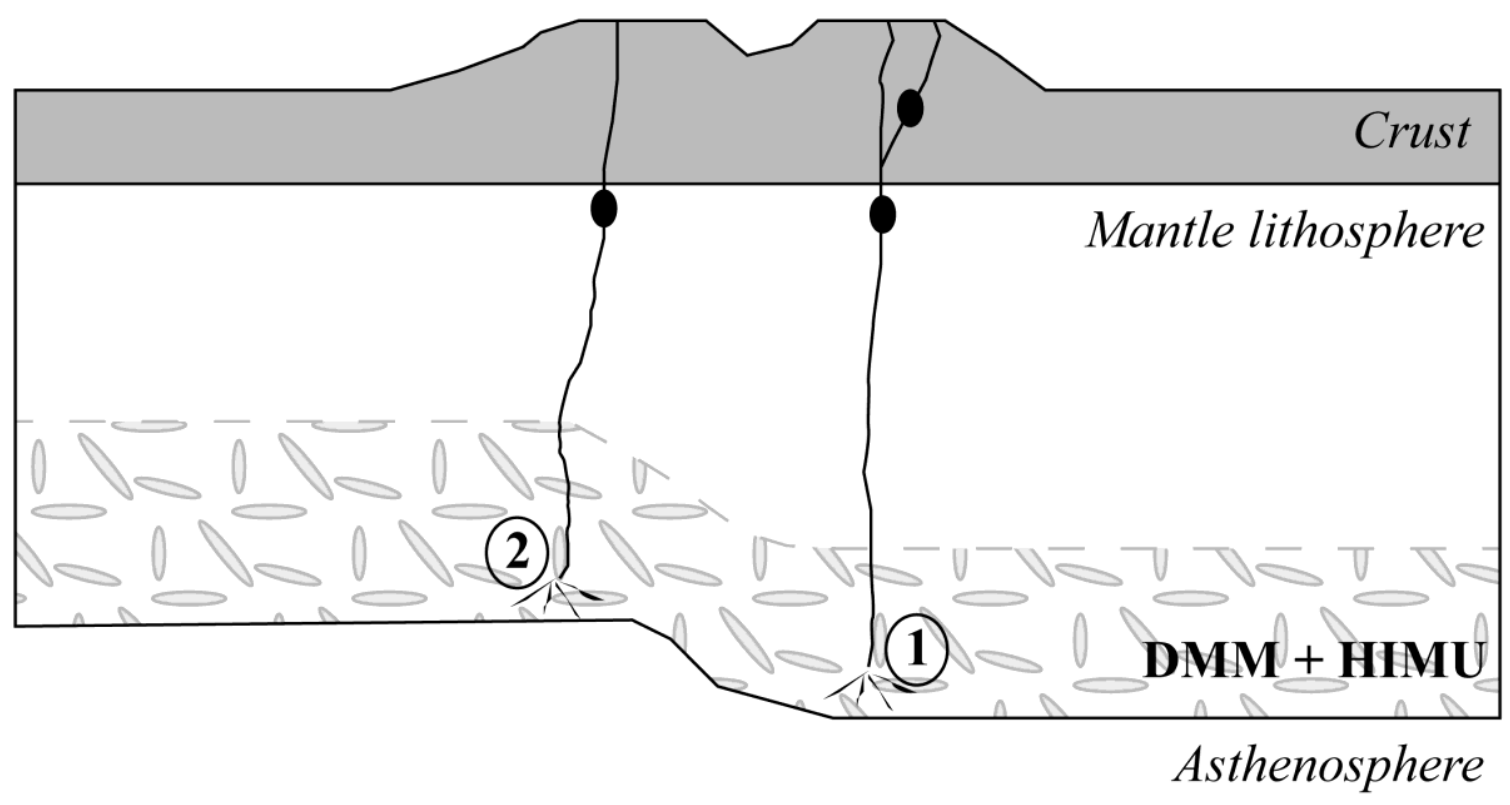

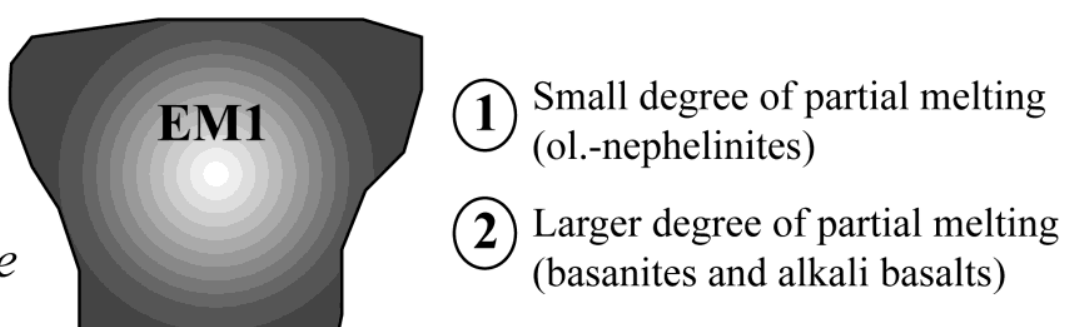

$875 \quad$ Fig. 11 
Table 1. Dating results from ${ }^{40} \mathrm{Ar}-{ }^{39} \mathrm{Ar}$ geochronology for Mayotte samples

\begin{tabular}{|c|c|c|c|c|c|c|c|c|c|c|c|c|c|c|}
\hline \multicolumn{4}{|c|}{ Sample } & \multicolumn{3}{|c|}{ Plateau age } & \multicolumn{5}{|c|}{ Inverse isochron age } & \multirow{2}{*}{\begin{tabular}{|c|}
$\begin{array}{c}\text { Integrated } \\
\text { age }\end{array}$ \\
Age $(\mathrm{Ma})$ \\
\end{tabular}} & \multirow{2}{*}{\begin{tabular}{|c|}
$\begin{array}{c}\text { Preferred } \\
\text { age }\end{array}$ \\
Age (Ma)
\end{tabular}} & \multirow[t]{2}{*}{ Remark } \\
\hline Unit & Number & Location & Petrological type & Type & $\begin{array}{l}\text { Age } \\
\text { (Ma) }\end{array}$ & Steps & Type & $\begin{array}{l}\text { Age } \\
\text { (Ma) }\end{array}$ & ${ }^{40} \mathrm{Ar} /{ }^{36} \mathrm{Ar}$ & MSWD & Steps & & & \\
\hline \multirow{6}{*}{ 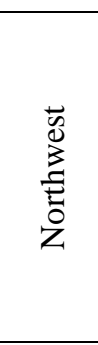 } & M104 & Lava flow & Basanite & SMA & $6.1 \pm 0.3$ & $1-3$ & \multirow{6}{*}{ NO } & $4.3 \pm 0.1$ & $311 \pm 10$ & 0,1 & $1-6$ & $5.0 \pm 0.1$ & $6.1 \pm 0.3$ & $\begin{array}{l}\text { SMA is maximum age } \\
\text { Data too clustered on isochron }\end{array}$ \\
\hline & M112 & Dyke & Ol.-nephelinite & SMA & $5.2 \pm 0.3$ & $1-3$ & & $4.4 \pm 1.0$ & $305 \pm 10$ & 2,4 & $1-5$ & $5.3 \pm 0.1$ & $4.4 \pm 1.0$ & \\
\hline & M108 & Dyke in M104 & Basanite & SMA & $3.8 \pm 0.1$ & $1-4$ & & $4.2 \pm 0.8$ & $291 \pm 10$ & 7,1 & $1-6,8$ & $3.2 \pm 0.1$ & $3.8 \pm 0.1$ & \\
\hline & M25 & Lava flow & Alkali basalt & NO & - & - & & $2.0 \pm 0.9$ & $382 \pm 46$ & 26,8 & $1-4$ & $3.2 \pm 0.1$ & $2.0 \pm 0.9$ & Maximum age \\
\hline & M20 & Dyke & Basanite & SMA & $\begin{array}{l}0.6 \pm \\
1.25\end{array}$ & $4-5$ & & - & - & - & - & $8.9 \pm 0.2$ & $<1 \mathrm{Ma}$ & Maximum age \\
\hline & M59 & Lava flow & Basanite & WMP & $0.8 \pm 0.2$ & $1-5$ & & $0.8 \pm 0.1$ & $303 \pm 150$ & 0,1 & $1-6$ & $0.8 \pm 0.2$ & $0.8 \pm 0.2$ & Data too clustered on isochron \\
\hline \multirow{6}{*}{ 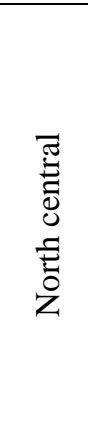 } & M97 & Lava flow & Basanite & SMA & $1.9 \pm 0.1$ & $1-5$ & \multirow{6}{*}{$\begin{array}{l}\mathrm{NO} \\
\mathrm{NO}\end{array}$} & $2.4 \pm 0.3$ & $291 \pm 6$ & 4,8 & $1-5$ & $1.8 \pm 0.1$ & $2.4 \pm 0.3$ & \\
\hline & M4 & Lava flow & Tephrite & $\mathrm{NO}$ & - & - & & $2.3 \pm 0.3$ & $240 \pm 30$ & 12,7 & $\begin{array}{l}1-3,5- \\
7\end{array}$ & $3.5 \pm 0.6$ & $2.3 \pm 0.3$ & Maximum age \\
\hline & M29 & Dome & Trachyte & NO & - & - & & - & - & - & - & $2.9 \pm 0.6$ & $<3 \mathrm{Ma}$ & Maximum age \\
\hline & M123 & Lava flow & Tephriphonolite & & $\begin{array}{l}1.2 \pm 0.1 \\
/ \\
1.4 \pm 0.1\end{array}$ & - & & - & - & - & - & $\begin{array}{l}1.2 \pm 0.1 / \\
1.4 \pm 0.1\end{array}$ & $1.4 \pm 0.1$ & \\
\hline & M56 & Lava flow & $\begin{array}{l}\text { Basaltic trachy- } \\
\text { andesite }\end{array}$ & SMA & $1.5 \pm 0.6$ & $1-3$ & & $1.4 \pm 0.1$ & $311 \pm 11$ & 2,6 & $1-4$ & $1.4 \pm 0.1$ & $1.4 \pm 0.1$ & \\
\hline & $\begin{array}{l}\text { M82 } \\
\text { M58 }\end{array}$ & $\begin{array}{l}\text { Lava flow } \\
\text { Lava flow }\end{array}$ & $\begin{array}{l}\text { Basanite } \\
\text { Phonolite }\end{array}$ & $\begin{array}{l}\text { SMA } \\
\text { SMA }\end{array}$ & $\begin{array}{l}1.4 \pm 0.1 \\
0.2 \pm 0.1\end{array}$ & $\begin{array}{l}1-4 \\
1-3\end{array}$ & & $\begin{array}{l}2.1 \pm 0.1 \\
0.8 \pm 0.1\end{array}$ & $\begin{array}{l}265 \pm 10 \\
345 \pm 18\end{array}$ & $\begin{array}{l}0,9 \\
4.3\end{array}$ & $\begin{array}{l}1-4 \\
1-6\end{array}$ & $\begin{array}{l}1.1 \pm 0.1 \\
0.6 \pm 0.1\end{array}$ & $\begin{array}{l}1.1 \pm 0.1 \\
0.8+0.1\end{array}$ & Nice isochron \\
\hline $\begin{array}{l}\text { Petite } \\
\text { Terre }\end{array}$ & M53 & $\begin{array}{l}\text { Strombolian } \\
\text { cone }\end{array}$ & Alkali basalt & NO & - & - & $\mathrm{NO}$ & - & - & - & - & $0.5 \pm 0.1$ & $0.2 \pm 0.1$ & All individual steps below $0.2 \mathrm{Ma}$ \\
\hline \multirow{10}{*}{$\begin{array}{l}\text { I } \\
\text { in }\end{array}$} & M137 & Lava flow & Ol.-nephelinite & NO & - & - & & $5.0 \pm 0.3$ & $319 \pm 2$ & 1,1 & $1-6$ & $13.1 \pm 0.2$ & $5.0 \pm 0.3$ & \multirow{10}{*}{$\begin{array}{l}\text { The integrated age is preferred to } \\
\text { badly defined plateau } \\
\text { Good plateau }\end{array}$} \\
\hline & M41 & Lava flow & Alkali basalt & $\mathrm{NO}$ & - & - & & $\begin{array}{l}10.6 \pm \\
0.5\end{array}$ & $270 \pm 20$ & 5,9 & $2-6$ & $6.2 \pm 0.1$ & $10.6 \pm 0.5$ & \\
\hline & M140 & Lava flow & Ol.-free neph. & WMP & $5.9 \pm 0.1$ & $1-4$ & & $6.1 \pm 0.1$ & $306 \pm 5$ & 2,2 & $1-5$ & $5.8 \pm 0.1$ & $5.9 \pm 0.1$ & \\
\hline & M93 & Lava flow & Ol.-nephelinite & NO & - & - & & $3.4 \pm 0.2$ & $308 \pm 6$ & 4,8 & $1-4$ & $4.4 \pm 0.1$ & $3.4 \pm 0.2$ & \\
\hline & M132 & Lava flow & Ol.- nephelinite & SMA & $3.8 \pm 0.1$ & $2-4$ & & $4.0 \pm 0.3$ & $302 \pm 7$ & 5,5 & $1-6$ & $4.7 \pm 0.1$ & $4.0 \pm 0.3$ & \\
\hline & M38 & Lava flow & Ol.-nephelinite & SMA & $4.6 \pm 0.1$ & $1-2$ & $\mathrm{NO}$ & - & - & - & - & $3.9 \pm 0.1$ & $3.9 \pm 0.1$ & \\
\hline & M39A & Dome & Phonolite & WMP & $3.9 \pm 0.4$ & $2-7$ & & $4.7 \pm 0.9$ & $263 \pm 49$ & 0,8 & $2-7$ & $4.3 \pm 0.1$ & $3.9 \pm 0.4$ & \\
\hline & M55 & Lava flow & Ol.-free neph. & NO & - & - & & $3.6 \pm 0.4$ & $291 \pm 42$ & 5,9 & $1-4,7$ & $3.8 \pm 0.5$ & $3.6 \pm 0.4$ & \\
\hline & M115 & Lava flow & Ol.-nephelinite & $\mathrm{NO}$ & - & - & & $1.9 \pm 0.2$ & $327 \pm 11$ & 6,4 & $1-7$ & $2.1 \pm 0.4$ & $1.9 \pm 0.2$ & \\
\hline & M95 & Lava flow & Ol.-nephelinite & SMA & $2.5 \pm 0.2$ & $1-2$ & $\mathrm{NO}$ & - & - & - & - & $1.5 \pm 0.8$ & $<2.5 \mathrm{Ma}$ & \\
\hline
\end{tabular}

For each sample, the plateau age and the isochron age are given when available; the preferred age is indicated in the last column.

MSWD: mean square weighted deviation. SMA: simple mean age, WMP: weighed plateau age.

Type of statistical approach: NO: no plateau or isochron could be calculated; SMA: simple mean age; WMP: weighed mean plateau age 
Table 2. Major and trace elements data for Mayotte

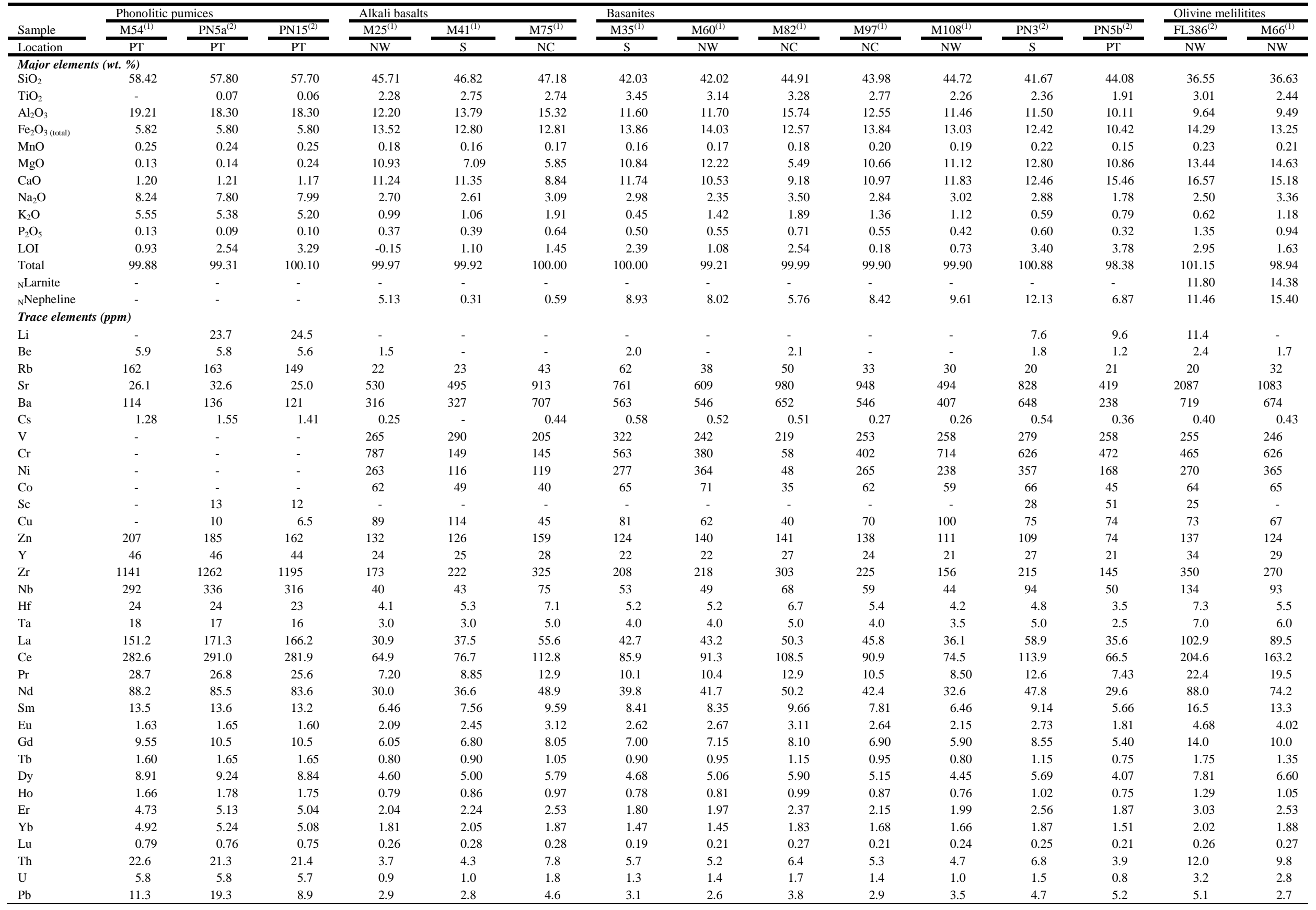




\begin{tabular}{|c|c|c|c|c|c|c|c|c|c|c|c|c|c|c|c|}
\hline \multirow[b]{2}{*}{ Sample } & \multicolumn{15}{|c|}{ Olivine nephelinites } \\
\hline & FL468 & $\mathrm{J} 2^{(2)}$ & $\mathrm{M} 19^{(1)}$ & ${\mathrm{M} 50^{(1)}}$ & $\mathrm{M} 88^{(1)}$ & $\mathrm{M} 89^{(1)}$ & $\mathrm{M} 112^{(1)}$ & M129 $9^{(1)}$ & $\mathrm{M} 132^{(1)}$ & ${\mathrm{M} 133^{(1)}}^{(1)}$ & M135 ${ }^{(1)}$ & $\mathrm{M} 137^{(1)}$ & M138 ${ }^{(1)}$ & $\mathrm{PN}^{2(2)}$ & PN12f $f^{(2)}$ \\
\hline Location & $\mathrm{S}$ & $\mathrm{S}$ & NW & $\mathrm{S}$ & $\mathrm{S}$ & $\mathrm{S}$ & $\mathrm{NW}$ & $S$ & $\mathrm{~S}$ & $\mathrm{~S}$ & $\mathrm{~S}$ & $\mathrm{~S}$ & $\mathrm{~S}$ & $\mathrm{~S}$ & $\bar{S}$ \\
\hline \multicolumn{16}{|c|}{ Major elements (wt. \%) } \\
\hline $\mathrm{SiO}_{2}$ & 41.36 & 42.15 & 39.84 & 40.09 & 39.32 & 40.47 & 43.44 & 38.30 & 40.90 & 40.40 & 41.28 & 40.54 & 38.72 & 38.90 & 38.10 \\
\hline $\mathrm{TiO}_{2}$ & 2.31 & 2.52 & 3.07 & 2.65 & 3.41 & 3.26 & 2.17 & 3.51 & 2.83 & 2.36 & 2.98 & 2.41 & 2.84 & 3.10 & 2.56 \\
\hline $\mathrm{Al}_{2} \mathrm{O}_{3}$ & 15.62 & 12.93 & 13.98 & 14.10 & 13.48 & 15.15 & 12.27 & 11.65 & 15.50 & 13.00 & 13.42 & 11.35 & 14.07 & 11.23 & 12.00 \\
\hline $\mathrm{Fe}_{2} \mathrm{O}_{3 \text { (total) }}$ & 12.98 & 12.45 & 14.43 & 12.81 & 12.58 & 12.77 & 12.91 & 12.86 & 12.06 & 11.74 & 12.52 & 12.20 & 12.56 & 13.67 & 12.70 \\
\hline $\mathrm{MnO}$ & 0.28 & 0.23 & 0.23 & 0.23 & 0.16 & 0.19 & 0.20 & 0.18 & 0.21 & 0.24 & 0.20 & 0.21 & 0.23 & 0.22 & 0.24 \\
\hline $\mathrm{MgO}$ & 6.11 & 7.85 & 6.71 & 6.69 & 8.23 & 6.70 & 10.68 & 9.97 & 6.01 & 8.90 & 8.33 & 13.88 & 6.68 & 10.21 & 10.30 \\
\hline $\mathrm{CaO}$ & 11.27 & 14.67 & 13.11 & 13.80 & 15.12 & 13.09 & 12.60 & 12.33 & 12.19 & 14.00 & 12.47 & 14.11 & 12.54 & 15.62 & 13.56 \\
\hline $\mathrm{Na}_{2} \mathrm{O}$ & 5.11 & 3.71 & 4.06 & 3.82 & 3.80 & 4.60 & 3.26 & 4.22 & 4.41 & 5.17 & 4.30 & 2.48 & 5.51 & 3.10 & 3.56 \\
\hline $\mathrm{K}_{2} \mathrm{O}$ & 1.70 & 0.91 & 1.48 & 1.18 & 0.80 & 1.07 & 1.45 & 0.86 & 2.61 & 2.32 & 1.04 & 1.18 & 1.76 & 0.81 & 0.93 \\
\hline $\mathrm{P}_{2} \mathrm{O}_{5}$ & 1.06 & 0.68 & 0.78 & 0.72 & 0.43 & 0.57 & 0.48 & 0.61 & 0.70 & 0.79 & 0.64 & 0.76 & 0.65 & 0.85 & 0.97 \\
\hline LOI & 2.73 & 2.84 & 2.20 & 3.93 & 2.63 & 2.13 & 0.66 & 4.02 & 2.63 & 0.72 & 2.45 & 0.59 & 3.49 & 2.59 & 4.55 \\
\hline Total & 100.54 & 100.93 & 99.89 & 100.02 & 99.96 & 100.00 & 100.12 & 98.51 & 100.05 & 99.64 & 99.63 & 99.62 & 99.05 & 100.31 & 99.47 \\
\hline${ }_{N}$ Larnite & - & - & 1.52 & 1.03 & 5.65 & 0.68 & - & 2.37 & 1.49 & 8.92 & - & 4.58 & 5.47 & 6.53 & 4.22 \\
\hline${ }_{N}$ Nepheline & 23.42 & 17.01 & 18.61 & 17.51 & 17.42 & 21.09 & 14.94 & 19.34 & 20.22 & 23.70 & 19.71 & 11.37 & 25.26 & 14.21 & 16.32 \\
\hline \multicolumn{16}{|c|}{ Trace elements (ppm) } \\
\hline $\mathrm{Li}$ & 13.3 & 10.5 & - & - & - & - & - & - & - & - & - & - & - & 10.3 & 16.0 \\
\hline $\mathrm{Be}$ & 3.5 & 2.8 & 3.0 & 2.6 & 1.5 & 2.0 & - & - & 2.8 & 2.1 & 2.1 & - & 2.6 & 2.3 & 2.6 \\
\hline $\mathrm{Rb}$ & 45 & 30 & 42 & 22 & 11 & 14 & 45 & 28 & 58 & 65 & 17 & 28 & 48 & 27 & 27 \\
\hline $\mathrm{Sr}$ & 1528 & 878 & 843 & 1064 & 727 & 873 & 645 & 757 & 1143 & 1297 & 815 & 746 & 1072 & 1154 & 1368 \\
\hline $\mathrm{Ba}$ & 946 & 858 & 920 & 875 & 587 & 829 & 568 & 587 & 849 & 1069 & 721 & 572 & 867 & 743 & 960 \\
\hline Cs & 0.80 & 2.65 & 1.05 & 0.65 & 0.36 & 0.54 & 0.62 & 0.36 & 0.68 & 0.65 & 0.78 & 0.24 & 1.20 & 0.55 & 0.20 \\
\hline $\mathrm{V}$ & 252 & 320 & 324 & 307 & 372 & 305 & 274 & 304 & 241 & 221 & 311 & 212 & 306 & 330 & 286 \\
\hline $\mathrm{Cr}$ & 62 & 183 & 76 & 110 & 180 & 77 & 581 & 451 & 109 & 315 & 507 & 547 & 182 & 337 & 332 \\
\hline $\mathrm{Ni}$ & 46 & 98 & 53 & 55 & 69 & 41 & 200 & 193 & 61 & 143 & 160 & 300 & 86 & 181 & 165 \\
\hline Co & 43 & 59 & 48 & 42 & 46 & 39 & 57 & 54 & 36 & 41 & 50 & 78 & 46 & 60 & 54 \\
\hline $\mathrm{Sc}$ & 16 & 32 & - & - & - & - & - & - & - & - & - & - & - & 30 & 23 \\
\hline $\mathrm{Cu}$ & 65 & 150 & 73 & 83 & 88 & 37 & 105 & 83 & 55 & 67 & 94 & 65 & 85 & 102 & 77 \\
\hline $\mathrm{Zn}$ & 145 & 118 & 143 & 124 & 96 & 113 & 117 & 107 & 135 & 116 & 128 & 118 & 135 & 123 & 124 \\
\hline $\mathrm{Y}$ & 40 & 31 & 31 & 29 & 24 & 27 & 24 & 23 & 31 & 37 & 29 & 24 & 29 & 32 & 33 \\
\hline $\mathrm{Zr}$ & 324 & 246 & 262 & 235 & 170 & 239 & 185 & 205 & 299 & 261 & 251 & 230 & 271 & 282 & 266 \\
\hline $\mathrm{Nb}$ & 175 & 115 & 104 & 122 & 59 & 89 & 67 & 70 & 97 & 115 & 86 & 74 & 99 & 111 & 131 \\
\hline $\mathrm{Hf}$ & 5.7 & 5.1 & 5.7 & 5.0 & 5.2 & 5.6 & 4.0 & 4.7 & 5.9 & 5.1 & 5.3 & 4.6 & 5.5 & 6.1 & 5.4 \\
\hline $\mathrm{Ta}$ & 9.0 & 5.0 & 7.0 & 6.5 & 4.5 & 6.5 & 4.5 & 5.0 & 7.5 & 7.5 & 6.5 & 5.0 & 6.5 & 5.5 & 7.0 \\
\hline $\mathrm{La}$ & 118.8 & 76.0 & 83.6 & 91.2 & 47.7 & 65.0 & 53.9 & 50.1 & 78.0 & 134.7 & 65.1 & 84.2 & 73.9 & 74.3 & 92.0 \\
\hline $\mathrm{Ce}$ & 221.6 & 140.6 & 151.9 & 168.0 & 99.6 & 129.1 & 98.2 & 99.4 & 145.7 & 218.9 & 125.4 & 120.1 & 136.0 & 140.0 & 168.3 \\
\hline $\operatorname{Pr}$ & 23.0 & 15.1 & 16.4 & 17.6 & 11.2 & 14.1 & 10.4 & 11.8 & 16.1 & 23.5 & 14.2 & 13.1 & 14.9 & 15.5 & 17.9 \\
\hline $\mathrm{Nd}$ & 81.8 & 56.5 & 59.2 & 65.6 & 45.3 & 53.5 & 38.8 & 46.6 & 62.1 & 81.9 & 54.9 & 49.1 & 56.0 & 59.7 & 67.1 \\
\hline $\mathrm{Sm}$ & 14.1 & 10.3 & 10.2 & 10.9 & 8.23 & 9.49 & 7.11 & 8.83 & 10.9 & 13.1 & 10.0 & 8.50 & 9.93 & 11.5 & 11.9 \\
\hline $\mathrm{Eu}$ & 3.98 & 3.01 & 3.18 & 3.31 & 2.55 & 2.92 & 2.21 & 2.71 & 3.38 & 3.89 & 3.12 & 2.67 & 3.06 & 3.38 & 3.49 \\
\hline $\mathrm{Gd}$ & 12.5 & 9.50 & 8.75 & 8.90 & 7.10 & 7.75 & 6.00 & 7.15 & 8.90 & 10.0 & 8.25 & 7.05 & 8.20 & 10.5 & 10.5 \\
\hline $\mathrm{Tb}$ & 1.65 & 1.25 & 1.20 & 1.20 & 0.95 & 1.05 & 0.85 & 0.95 & 1.25 & 1.40 & 1.15 & 0.95 & 1.15 & 1.35 & 1.40 \\
\hline Dy & 7.74 & 6.13 & 6.38 & 6.05 & 5.00 & 5.68 & 4.65 & 4.96 & 6.40 & 7.35 & 6.04 & 5.08 & 6.08 & 6.79 & 7.05 \\
\hline Ho & 1.44 & 1.13 & 1.12 & 1.04 & 0.90 & 0.99 & 0.82 & 0.83 & 1.16 & 1.28 & 1.02 & 0.81 & 1.06 & 1.20 & 1.28 \\
\hline $\mathrm{Er}$ & 3.65 & 2.86 & 2.96 & 2.70 & 2.27 & 2.55 & 2.06 & 1.98 & 2.88 & 3.36 & 2.59 & 2.16 & 2.65 & 2.97 & 3.25 \\
\hline $\mathrm{Yb}$ & 2.90 & 2.17 & 2.38 & 2.15 & 1.84 & 2.08 & 1.91 & 1.52 & 2.34 & 2.74 & 2.13 & 1.75 & 2.24 & 2.20 & 2.51 \\
\hline $\mathrm{Lu}$ & 0.40 & 0.29 & 0.35 & 0.31 & 0.27 & 0.31 & 0.27 & 0.21 & 0.33 & 0.39 & 0.30 & 0.25 & 0.33 & 0.29 & 0.34 \\
\hline Th & 13.0 & 9.6 & 10.6 & 9.1 & 6.6 & 8.8 & 7.1 & 5.4 & 10.0 & 13.5 & 7.2 & 9.1 & 8.0 & 8.4 & 10.4 \\
\hline U & 5.1 & 2.2 & 2.3 & 2.2 & 1.6 & 2.0 & 1.6 & 1.3 & 2.6 & 3.2 & 1.5 & 2.0 & 1.9 & 2.1 & 3.1 \\
\hline $\mathrm{Pb}$ & 7.4 & 5.8 & 6.0 & 5.3 & 3.3 & 4.2 & 4.7 & 7.6 & 6.2 & 7.9 & 4.3 & 4.7 & 11.0 & 5.0 & 6.4 \\
\hline
\end{tabular}




\begin{tabular}{|c|c|c|c|c|c|c|c|c|c|c|c|c|c|c|c|}
\hline \multirow[b]{2}{*}{ Sample } & \multicolumn{2}{|c|}{ Olivine-free nephelinites } & \multicolumn{2}{|l|}{ Tephrites } & \multicolumn{4}{|c|}{ Tephri-phonolites } & \multicolumn{7}{|l|}{ Phonolites } \\
\hline & $\mathrm{M} 140^{(1)}$ & $\mathrm{PN}^{(2)}$ & $\mathrm{J}^{(2)}$ & $\mathrm{M} 4^{(1)}$ & FL478 ${ }^{(2)}$ & M91 ${ }^{(1)}$ & ${\mathrm{M} 123^{(1)}}^{(1)}$ & $\mathrm{M} 127^{(1)}$ & FL426(2) & FL442(2) & M58 ${ }^{(1)}$ & ${\mathrm{M} 103^{(1)}}^{(1)}$ & M131 ${ }^{(1)}$ & $\mathrm{PN}^{(2)}$ & ${\mathrm{PN} 11^{(2)}}^{2}$ \\
\hline Location & $\mathrm{S}$ & $\mathrm{S}$ & $\mathrm{NC}$ & $\mathrm{NC}$ & $\mathrm{S}^{\mathrm{C}}$ & $\mathrm{S}$ & $\mathrm{NC}$ & NW & $\mathrm{S}^{\mathrm{C}}$ & $S^{\mathrm{C}}$ & $\mathrm{NC}$ & $\mathrm{S}^{\mathrm{C}}$ & $\mathrm{S}$ & $\mathrm{S}$ & $\mathrm{NC}$ \\
\hline \multicolumn{16}{|c|}{ Major elements (wt. \%) } \\
\hline $\mathrm{SiO}_{2}$ & 47.15 & 46.02 & 49.02 & 46.38 & 49.94 & 50.24 & 55.00 & 51.66 & 53.55 & 54.58 & 58.98 & 54.34 & 54.47 & 53.91 & 55.85 \\
\hline $\mathrm{TiO}_{2}$ & 1.09 & 1.26 & 2.46 & 2.94 & 1.70 & 0.67 & 1.22 & 1.03 & 0.48 & 0.49 & 0.33 & 0.71 & 0.25 & 0.31 & 0.30 \\
\hline $\mathrm{Al}_{2} \mathrm{O}_{3}$ & 20.41 & 18.82 & 16.16 & 15.18 & 17.70 & 19.96 & 19.43 & 18.22 & 19.31 & 20.48 & 20.00 & 20.16 & 20.39 & 19.07 & 21.42 \\
\hline $\mathrm{Fe}_{2} \mathrm{O}_{3 \text { (total) }}$ & 7.89 & 7.88 & 10.91 & 12.42 & 9.42 & 6.54 & 6.21 & 8.31 & 5.80 & 4.78 & 3.49 & 5.62 & 4.37 & 5.67 & 2.75 \\
\hline $\mathrm{MnO}$ & 0.22 & 0.29 & 0.18 & 0.17 & 0.25 & 0.27 & 0.14 & 0.28 & 0.27 & 0.19 & 0.14 & 0.19 & 0.22 & 0.29 & 0.17 \\
\hline $\mathrm{MgO}$ & 1.85 & 1.97 & 4.26 & 5.50 & 2.40 & 0.90 & 1.53 & 0.73 & 0.78 & 0.90 & 0.21 & 1.35 & 0.41 & 0.33 & 0.24 \\
\hline $\mathrm{CaO}$ & 6.85 & 6.15 & 7.28 & 9.08 & 5.13 & 4.17 & 4.19 & 3.73 & 2.34 & 1.65 & 1.32 & 2.51 & 1.54 & 1.29 & 1.30 \\
\hline $\mathrm{Na}_{2} \mathrm{O}$ & 6.79 & 8.25 & 4.82 & 4.27 & 7.38 & 7.25 & 6.60 & 8.07 & 8.24 & 9.37 & 8.03 & 8.95 & 8.77 & 8.29 & 9.61 \\
\hline $\mathrm{K}_{2} \mathrm{O}$ & 4.17 & 4.46 & 2.67 & 2.08 & 4.42 & 5.69 & 4.21 & 5.43 & 4.57 & 5.25 & 5.70 & 4.98 & 5.37 & 6.35 & 5.72 \\
\hline $\mathrm{P}_{2} \mathrm{O}_{5}$ & 0.35 & 0.31 & 0.74 & 0.62 & 0.65 & 0.17 & 0.39 & 0.32 & 0.17 & 0.15 & 0.05 & 0.27 & 0.05 & 0.02 & 0.03 \\
\hline LOI & 3.32 & 4.13 & 0.59 & 1.35 & 1.26 & 4.25 & 1.11 & 2.61 & 3.12 & 1.22 & 1.65 & 1.02 & 4.09 & 3.78 & 1.32 \\
\hline Total & 100.09 & 99.15 & 99.09 & 98.64 & 100.25 & 100.11 & 100.03 & 100.39 & 98.63 & 99.07 & 99.90 & 100.10 & 99.93 & 98.75 & 98.71 \\
\hline${ }_{N}$ Larnite & - & - & - & - & - & - & - & - & - & - & - & - & - & - & - \\
\hline${ }_{N} N e p h e l i n e$ & - & - & - & - & - & - & - & - & - & - & - & - & - & - & - \\
\hline \multicolumn{16}{|c|}{ Trace elements (ppm) } \\
\hline $\mathrm{Li}$ & - & 21.5 & 14.0 & - & 13.4 & - & - & - & 7.1 & 14.4 & - & - & - & 2.6 & 17.6 \\
\hline $\mathrm{Be}$ & 4.5 & 7.3 & 3.5 & 2.5 & 3.3 & 7.5 & 3.4 & 4.3 & 6.7 & 4.2 & 8.2 & 2.1 & 8.7 & 10.7 & 6.9 \\
\hline $\mathrm{Rb}$ & 131 & 146 & 78.1 & 30.7 & 146 & 214 & 104 & 174 & 230 & 172 & 187 & 150 & 162 & 242 & 202 \\
\hline $\mathrm{Sr}$ & 1341 & 1828 & 1091 & 964 & 1916 & 1284 & 1040 & 1428 & 668 & 1439 & 213 & 1520 & 764 & 1035 & 268 \\
\hline $\mathrm{Ba}$ & 1262 & 2064 & 856 & 788 & 1350 & 1380 & 1084 & 1765 & 506 & 811 & 561 & 1032 & 277 & 764 & 206 \\
\hline Cs & 1.28 & 1.21 & 1.08 & 1.24 & 1.29 & 1.95 & 1.34 & 0.83 & 2.09 & 1.43 & 1.90 & 2.30 & 2.13 & 1.32 & 2.58 \\
\hline $\mathrm{V}$ & 64 & 107 & 177 & 224 & 103 & 53 & 54 & 15.7 & 10.8 & 11 & 2.8 & 31 & 9.2 & 9.1 & 15 \\
\hline $\mathrm{Cr}$ & - & 3.5 & 59 & 153 & 12 & - & - & - & 1.2 & 11 & - & 19 & - & - & 0.4 \\
\hline $\mathrm{Ni}$ & - & 3.0 & 55 & 90 & 15 & - & 5.5 & - & 1.7 & 12 & - & 18 & - & - & 0.5 \\
\hline Co & 12 & 12 & 35 & 44 & 16 & 5.5 & 10 & 5.2 & 2.3 & 3.2 & 1.2 & 5.8 & 1.0 & 1.4 & 1.4 \\
\hline $\mathrm{Sc}$ & - & 2.0 & 14 & - & 5.4 & - & - & - & 1.6 & 1.4 & - & - & - & 0.9 & 1.1 \\
\hline $\mathrm{Cu}$ & 16 & 12 & 41 & 53 & 15 & 4.8 & 11 & - & 0.7 & 1.9 & - & 5.9 & - & 0.5 & 1.2 \\
\hline $\mathrm{Zn}$ & 156 & 179 & 154 & 155 & 146 & 194 & 135 & 172 & 189 & 132 & 144 & 128 & 175 & 246 & 137 \\
\hline $\mathrm{Y}$ & 33 & 53 & 31 & 27 & 47 & 38 & 25 & 41 & 36 & 27 & 24 & 28 & 32 & 55 & 19 \\
\hline $\mathrm{Zr}$ & 340 & 596 & 529 & 350 & 668 & 594 & 640 & 790 & 1067 & 846 & 879 & 731 & 701 & 862 & 953 \\
\hline $\mathrm{Nb}$ & 145 & 240 & 126 & 86 & 233 & 182 & 113 & 159 & 317 & 257 & 132 & 175 & 151 & 298 & 164 \\
\hline $\mathrm{Hf}$ & 6.0 & 7.5 & 9.3 & 8.2 & 11.4 & 7.9 & 11.2 & 12.5 & 18.2 & 15.4 & 14.1 & 13.1 & 8.7 & 10.2 & 13.4 \\
\hline $\mathrm{Ta}$ & 9.0 & 8.0 & 6.0 & 6.0 & 13 & 5.0 & 9.5 & 14 & 18 & 17 & 10 & 16 & 6.0 & 5.0 & 4.5 \\
\hline $\mathrm{La}$ & 116.1 & 154.4 & 74.4 & 65.2 & 127.0 & 97.2 & 79.3 & 113.7 & 66.0 & 65.3 & 98.7 & 78.4 & 85.8 & 102.9 & 81.7 \\
\hline $\mathrm{Ce}$ & 191.6 & 243.2 & 138.2 & 125.8 & 224.1 & 142.8 & 145.4 & 203.0 & 126.6 & 123.1 & 138.3 & 141.9 & 140.8 & 168.4 & 106.0 \\
\hline $\operatorname{Pr}$ & 19.5 & 22.1 & 15.0 & 13.8 & 22.9 & 14.6 & 15.2 & 23.3 & 13.6 & 12.8 & 12.0 & 15.3 & 12.5 & 14.8 & 7.99 \\
\hline $\mathrm{Nd}$ & 64.4 & 73.2 & 55.6 & 52.4 & 80.2 & 45.8 & 48.2 & 83.5 & 47.9 & 44.9 & 35.3 & 54.3 & 38.7 & 45.2 & 21.2 \\
\hline $\mathrm{Sm}$ & 9.94 & 11.9 & 10.5 & 9.72 & 14.0 & 7.37 & 7.16 & 13.8 & 8.98 & 7.93 & 4.83 & 8.81 & 6.14 & 7.60 & 2.83 \\
\hline $\mathrm{Eu}$ & 3.16 & 3.53 & 3.19 & 3.14 & 4.21 & 2.33 & 2.51 & 4.13 & 2.66 & 2.50 & 1.22 & 2.92 & 1.91 & 2.41 & 0.78 \\
\hline $\mathrm{Gd}$ & 7.80 & 10.5 & 9.40 & 3.75 & 12.0 & 6.40 & 5.95 & 10.0 & 8.15 & 6.90 & 3.35 & 6.50 & 4.80 & 7.65 & 2.45 \\
\hline $\mathrm{Tb}$ & 1.15 & 1.50 & 1.30 & 1.05 & 1.65 & 1.00 & 0.85 & 1.50 & 1.20 & 1.00 & 0.55 & 0.95 & 0.80 & 1.30 & 0.40 \\
\hline Dy & 6.48 & 8.35 & 6.28 & 5.90 & 8.41 & 6.23 & 4.59 & 8.43 & 6.74 & 5.25 & 3.65 & 5.37 & 5.60 & 7.78 & 2.44 \\
\hline Ho & 1.17 & 1.64 & 1.14 & 0.89 & 1.58 & 1.23 & 0.82 & 1.42 & 1.32 & 1.02 & 0.71 & 0.85 & 1.06 & 1.64 & 0.56 \\
\hline $\mathrm{Er}$ & 3.22 & 4.67 & 2.79 & 2.39 & 4.19 & 3.72 & 2.31 & 3.96 & 3.86 & 2.84 & 1.97 & 2.50 & 3.21 & 5.25 & 1.87 \\
\hline $\mathrm{Yb}$ & 3.04 & 4.02 & 2.21 & 1.89 & 3.40 & 3.92 & 1.95 & 4.13 & 3.84 & 2.65 & 2.47 & 2.60 & 3.41 & 5.19 & 2.31 \\
\hline $\mathrm{Lu}$ & 0.45 & 0.53 & 0.29 & 0.29 & 0.47 & 0.57 & 0.31 & 0.60 & 0.54 & 0.38 & 0.35 & 0.39 & 0.50 & 0.71 & 0.34 \\
\hline Th & 22.3 & 30.1 & 11.5 & 9.6 & 15.7 & 25.5 & 19.5 & 20.0 & 24.6 & 12.9 & 24.8 & 12.7 & 27.7 & 34.1 & 24.1 \\
\hline $\mathrm{U}$ & 5.0 & 5.1 & 3.2 & 2.6 & 5.4 & 7.6 & 4.9 & 4.6 & 6.7 & 3.5 & 3.9 & 4.3 & 7.4 & 10.3 & 8.4 \\
\hline $\mathrm{Pb}$ & 12.7 & 23.4 & 5.9 & 5.0 & 5.3 & 20.8 & 9.6 & 11.4 & 12.3 & 7.5 & 16.2 & 7.2 & 17.9 & 26.3 & 11.2 \\
\hline
\end{tabular}

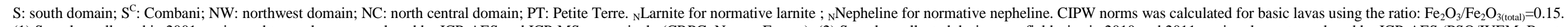

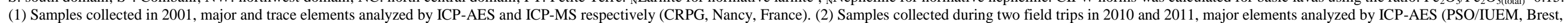
France) following the analytical method described by Cotten et al (1995), trace elements analyzed by ICP-MS (PSO/IUEM, Brest, France) following the sample preparation and analysis method of Barrat et al (1996). 
Table 3. $\mathrm{Sr}, \mathrm{Nd}, \mathrm{Pb}$ isotopic data for Mayotte.

(1) S: south domain; $S^{C}$ : Combani Massif; NW: northwest domain; NC: north central domain; PT: Petite Terre domain (see Fig. 2c for domain location).

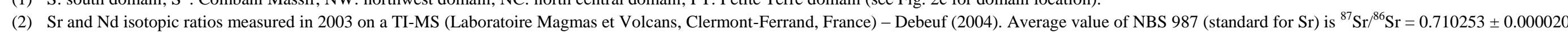

\begin{tabular}{|c|c|c|c|c|c|c|c|c|c|c|c|c|}
\hline Sample & Rock Type & Location $^{(1)}$ & ${ }^{87} \mathrm{Sr} /{ }^{86} \mathrm{Sr}$ & $2 \sigma$ & ${ }^{143} \mathrm{Nd} /{ }^{144} \mathrm{Nd}$ & $2 \sigma$ & ${ }^{206} \mathrm{~Pb} /{ }^{204} \mathrm{~Pb}$ & $2 \sigma$ & ${ }^{207} \mathrm{~Pb} /{ }^{204} \mathrm{~Pb}$ & $2 \sigma$ & ${ }^{208} \mathrm{~Pb} /{ }^{204} \mathrm{~Pb}$ & $2 \sigma$ \\
\hline PN5a & Phon. pumice & PT & - & - & $0.512856^{(4)}$ & 0.000008 & $19.4841^{(4)}$ & 0.0006 & $15.6263^{(4)}$ & 0.0006 & $39.377^{(4)}$ & 0.002 \\
\hline M25 & Alkali basalt & NW & $0.703350^{(2)}$ & 0.000006 & $0.512860^{(4)}$ & 0.000004 & $20.2819^{(4)}$ & 0.0006 & $15.6699^{(4)}$ & 0.0007 & $39.965^{(4)}$ & 0.002 \\
\hline M41 & Alkali basalt & $\mathrm{S}$ & $0.703830^{(2)}$ & 0.000006 & $0.512720^{(2)}$ & 0.000004 & - & - & - & - & - & - \\
\hline M60 & Basanite & NW & $0.703300^{(2)}$ & 0.000006 & $0.512860^{(2)}$ & 0.000004 & - & - & - & - & - & - \\
\hline M82 & Basanite & $\mathrm{NC}$ & - & - & $0.512860^{(2)}$ & 0.000004 & - & - & - & - & - & - \\
\hline M97 & Basanite & $\mathrm{NC}$ & $0.703350^{(2)}$ & 0.000006 & $0.512880^{(2)}$ & 0.000004 & $19.1269^{(4)}$ & 0.0006 & $15.5746^{(4)}$ & 0.0006 & $39.059^{(4)}$ & 0.002 \\
\hline M108 & Basanite & NW & $0.703390^{(2)}$ & 0.000006 & $0.512820^{(2)}$ & 0.000004 & $20.3206^{(4)}$ & 0.0008 & $15.6738^{(4)}$ & 0.0007 & $40.028^{(4)}$ & 0.002 \\
\hline PN3 & Basanite & $\mathrm{S}$ & $0.703241^{(3)}$ & 0.000006 & $0.512862^{(3)}$ & 0.000010 & $20.1820^{(3)}$ & 0.0010 & $15.6641^{(3)}$ & 0.0009 & $39.929^{(3)}$ & 0.003 \\
\hline PN5b & Basanite & $\mathrm{PT}$ & - & - & $0.512784^{(4)}$ & 0.000004 & $19.8709^{(4)}$ & 0.0009 & $15.6698^{(4)}$ & 0.0008 & $39.718^{(4)}$ & 0.003 \\
\hline FL386 & Ol.-melilitite & NW & $0.703254^{(3)}$ & 0.000006 & $0.512860^{(3)}$ & 0.000008 & $19.4139^{(3)}$ & 0.0007 & $15.6150^{(3)}$ & 0.0007 & $39.282^{(3)}$ & 0.002 \\
\hline M66 & Ol.-melilitite & NW & - & - & $0.512864^{(4)}$ & 0.000003 & $19.5269^{(4)}$ & 0.0006 & $15.6238^{(4)}$ & 0.0006 & $39.379^{(4)}$ & 0.002 \\
\hline FL468 & Ol.-nephelinite & $\mathrm{S}$ & $0.703307^{(3)}$ & 0.000006 & $0.512823^{(3)}$ & 0.000004 & $20.1553^{(3)}$ & 0.0008 & $15.6589^{(3)}$ & 0.0007 & $39.883^{(3)}$ & 0.002 \\
\hline $\mathrm{J} 2$ & Ol.-nephelinite & $\mathrm{S}$ & $0.703418^{(3)}$ & 0.000008 & $0.512795^{(3)}$ & 0.000006 & $20.1919^{(3)}$ & 0.0006 & $15.6664^{(3)}$ & 0.0006 & $39.930^{(3)}$ & 0.002 \\
\hline M112 & Ol.-nephelinite & NW & $0.703380^{(2)}$ & 0.000006 & $0.512820^{(2)}$ & 0.000004 & $20.2677^{(4)}$ & 0.0006 & $15.6606^{(4)}$ & 0.0008 & $39.961^{(4)}$ & 0.003 \\
\hline M132 & Ol.-nephelinite & $\mathrm{S}$ & $0.703410^{(2)}$ & 0.000006 & $0.512860^{(2)}$ & 0.000004 & $20.2718^{(4)}$ & 0.0007 & $15.6700^{(4)}$ & 0.0006 & $39.993^{(4)}$ & 0.002 \\
\hline M133 & Ol.-nephelinite & $\mathrm{S}$ & - & - & $0.512820^{(4)}$ & 0.000004 & $20.0849^{(4)}$ & 0.0005 & $15.6608^{(4)}$ & 0.0005 & $39.856^{(4)}$ & 0.001 \\
\hline M137 & Ol.-nephelinite & $\mathrm{S}$ & $0.703320^{(2)}$ & 0.000006 & $0.512860^{(2)}$ & 0.000004 & $19.5055^{(4)}$ & 0.0005 & $15.6096^{(4)}$ & 0.0006 & $39.391^{(4)}$ & 0.002 \\
\hline PN2 & Ol.-nephelinite & $\mathrm{S}$ & $0.703253^{(3)}$ & 0.000006 & $0.512851^{(3)}$ & 0.000004 & $20.0507^{(3)}$ & 0.0009 & $15.6482^{(3)}$ & 0.0009 & $39.799^{(3)}$ & 0.003 \\
\hline PN12f & Ol.-nephelinite & $\mathrm{S}$ & - & - & $0.512833^{(4)}$ & 0.000004 & $20.3627^{(4)}$ & 0.0007 & $15.6746^{(4)}$ & 0.0007 & $40.091^{(4)}$ & 0.002 \\
\hline M140 & Ol.-free neph. & $\mathrm{S}$ & $0.703410^{(2)}$ & 0.000006 & $0.512800^{(2)}$ & 0.000004 & - & - & - & - & - & - \\
\hline PN8 & Ol.-free neph. & $\mathrm{S}$ & $0.703269^{(3)}$ & 0.000008 & $0.512858^{(3)}$ & 0.000006 & $20.2067^{(3)}$ & 0.0008 & $15.6645^{(3)}$ & 0.0007 & $39.957^{(3)}$ & 0.002 \\
\hline $\mathrm{J} 7$ & Tephrite & $\mathrm{NC}$ & $0.703333^{(3)}$ & 0.000008 & $0.512891^{(3)}$ & 0.000006 & $19.1695^{(3)}$ & 0.0007 & $15.5792^{(3)}$ & 0.0007 & $39.085^{(3)}$ & 0.002 \\
\hline M56 & Bas. trachy-and. & $\mathrm{NC}$ & $0.703280^{(3)}$ & 0.000006 & $0.512890^{(2)}$ & 0.000004 & - & - & - & - & - & - \\
\hline FL426 & Phonolite & $\mathrm{S}^{\mathrm{C}}$ & - & - & $0.512848^{(4)}$ & 0.000004 & $19.7492^{(4)}$ & 0.0009 & $15.6219^{(4)}$ & 0.0008 & $39.588^{(4)}$ & 0.003 \\
\hline M123 & Tephriphonolite & $\mathrm{NC}$ & $0.703310^{(2)}$ & 0.000006 & $0.512880^{(2)}$ & 0.000004 & - & - & - & - & - & - \\
\hline FL442 & Phonolite & $\mathrm{S}^{\mathrm{C}}$ & $0.703198^{(3)}$ & 0.000006 & $0.512871^{(3)}$ & 0.000006 & $19.6438^{(3)}$ & 0.0004 & $15.6084^{(3)}$ & 0.0003 & $39.487^{(3)}$ & 0.001 \\
\hline M58 & Phonolite & $\mathrm{NC}$ & $0.703410^{(2)}$ & 0.000006 & $0.512870^{(2)}$ & 0.000004 & - & - & - & - & - & - \\
\hline PN7 & Phonolite & $S$ & - & - & $0.512834^{(4)}$ & 0.000004 & $20.3548^{(4)}$ & 0.0006 & $15.6775^{(4)}$ & 0.0006 & $40.075^{(4)}$ & 0.002 \\
\hline PN11 & Phonolite & $\mathrm{NC}$ & $0.703263^{(3)}$ & 0.000006 & $0.512899^{(3)}$ & 0.000004 & $19.3220^{(3)}$ & 0.0007 & $15.5964^{(3)}$ & 0.0007 & $39.215^{(3)}$ & 0.002 \\
\hline
\end{tabular}

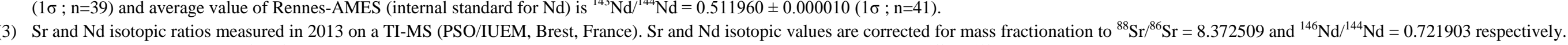

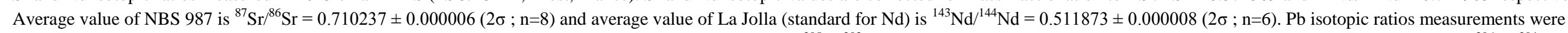

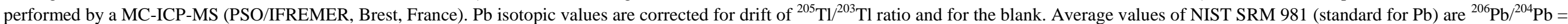
$16.9314 \pm 0.0005(2 \sigma ; \mathrm{n}=7) ;{ }^{207} \mathrm{~Pb} /{ }^{204} \mathrm{~Pb}=15.4850 \pm 0.0006(2 \sigma ; \mathrm{n}=7) ;{ }^{208} \mathrm{~Pb} /{ }^{204} \mathrm{~Pb}=36.6764 \pm 0.0018(2 \sigma ; \mathrm{n}=7)$.

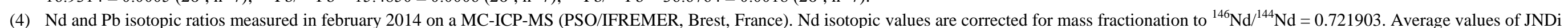

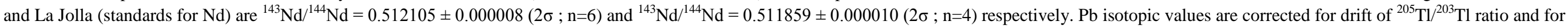

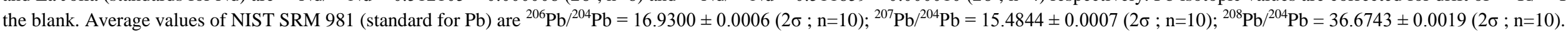

